\title{
ARABSKIE ZAPOŻYCZENIA LEKSYKALNE W JEZZYKU HISZPAŃSKIM
}

\author{
Jamila Oueslati, Agata Wolarska
}

\begin{abstract}
The large number of words from Arabic found in modern Spanish is proof of the deep influence Arabic has had on the Spanish language. Historical sociolinguistic processes which have lasted to the present day indicate that the influence of Arabic culture has been neither brief or superficial. Instead, it has, and continues to have great significance for the language situation of Spain. Much linguistic research has shown how loans from Arabic have been assimilated as they have become part of the lexical resources of modern Spanish. Arabic culture and civilization in the Iberian Peninsula (711-1942) above all involved the sciences, literature, art, architecture, engineering, agriculture, the military, medicine. At that time, Al-Andalus was one of the most influential European centers of science and cultural exchange in Europe. Contacts between Arabic and the Romance languages found in the Iberian Peninsula resulted in numerous loans both from Arabic to the Romance languages and from the Romance languages to Arabic. These topics have been the subject of extensive research conducted from historical, cultural and linguistic points of view. Despite the existence of numerous works concerning Arabic loans, this area requires, further, deeper research. In this article, selected issues concerning Arabic loans in Spanish are analyzed as are the adaptive processes they have undergone and the level of their integration into Spanish. The basis of the analysis is made up of oral and written texts collected in the Corpus de Español del Siglo XXI [CORPES XXI, RAE $]^{1}$ - a corpus of contemporary Spanish from the $21^{\text {st }}$ century.
\end{abstract}

Key words: loans, Arabic loanwords, loanwords in Spanish, Arabic loanwords in Spanish, adaptive processes, Arabic language, Spanish language

\section{Uwagi wstępne}

W niniejszym opracowaniu autorki koncentrują się na wpływie, jaki wywarł oraz nadal wywiera język arabski na język hiszpański. Celem przeprowadzonej

\footnotetext{
${ }^{1}$ REAL ACADEMIA ESPAÑOLA: Banco de datos (CORPES XXI) [online], Corpus del Español del Siglo XXI (CORPES). <http://www.rae.es>
} 
analizy jest sprawdzenie, jak bardzo zakorzenione są zapożyczenia z języka arabskiego w języku hiszpańskim. Badanie koncentruje się nie na liczbie zapożyczeń, tylko na sposobie integracji wybranych słów (materiał badawczy) ze współczesnym językiem hiszpańskim. Przeprowadzona analiza nie ma na celu bezpośredniego wykazania liczby arabizmów w j. hiszpańskim, chociaż ten aspekt (ilościowy) jest brany pod uwagę i znaczący. Badanie wspomnianej integracji opiera się na dwóch źródłach - słowniku DRAE $E^{2}$ i korpusie współczesnego języka hiszpańskiego CORPES XXI oraz analizie materiału badawczego przeprowadzonej wg pięciu wymiarów przedstawionych $\mathrm{w}$ rozdziale czwartym (metodologia) i piątym (analiza). Powyższa tematyka wymaga przypomnienia podstawowych zagadnień teorii zapożyczeń.

Termin zapożyczenie (z ang. loan), stosowany w językoznawstwie porównawczym i historycznym, w słownikach terminologicznych oznacza wejście elementu jednego języka (A) do drugiego języka (B), i oznacza formy językowe ( $\mathrm{z}$ ang. forms), które przeszły z jednego języka / dialektu (A) do drugiego języka lub dialektu (B). Elementy zapożyczone mogą pochodzić z podsystemu leksykalnego (słowa, wyrażenia, zwroty $-\mathrm{z}$ ang. loan words), fonetycznego (głoski $-\mathrm{z}$ ang. sounds) czy dotyczyć struktur gramatycznych (z ang. grammactical structures) i nazywamy je zapożyczeniami językowymi. Należy jednak nadmienić, że wg E. Mańczak-Wohlfeld nazwa zapożyczenie nie jest odpowiednia, ponieważ (...) kojarzy się z czymś, co podlega zwrotowi, a nie zostało dane na zawsze. Jak powszechnie wiadomo, zapożyczenia językowe to elementy obcego języka, które sa przyswojone przez inne języki i zatrzymane na state. ${ }^{3}$ Nieadekwatność tę komentuje też E. Haugen ${ }^{4}$, a uwaga ta dotyczy omawianego pojęcia również w innych językach, np. w angielskim (borrowing), francuskim (emprunt), hiszpańskim (préstamo) czy arabskim (isti'āra / iqtirāẹ). Zatem zapożyczenie językowe wyklucza „zwrot” przyswojonego elementu. Funkcjonuje on w systemie języka docelowego, a filtr stanowi uzus jego użycia $\mathrm{w}$ tym języku - funkcjonuje i rozwija się w języku, do którego wszedł $\mathrm{w}$ formie zapożyczenia lub z czasem zanika (np. niektóre głoski).

Możemy wyróżnić trzy podstawowe powody zapożyczeń:

1) brak np. nazw / określeń (zwierzęta, rośliny, jedzenie, potrawy, napoje, geografia) w języku zapożyczającym (B) na określenie danej rzeczy lub zjawiska występujących w języku (A);

2) dominacja polityczna, naukowa, kulturowa języka (A), która niejako wymusza zapożyczenia do języka (B), przykład może stanowić słownictwo związane $\mathrm{z}$ nowoczesnymi technologiami pochodzące $\mathrm{z} \mathrm{j}$. angielskiego -

${ }^{2}$ REAL ACADEMIA ESPAÑOLA: Diccionario de la lengua española, 23 edycja [wersja 23.4 online], $<$ https://dle.rae.es $>$

${ }^{3}$ Mańczak-Wohlfeld (1995: 14).

${ }^{4}$ Por. Haugen (1950: 211-212). 
współcześnie „kupujemy” technologię wraz z całą nomenklaturą i wiedzą. $\mathrm{Z}$ j. arabskim historycznie miało miejsce podobne zjawisko na terenach Al-Andalus, które jako ośrodek kultury, medycyny, nauki, etc. ówcześnie dominujący narzucał również swoje nazewnictwo w różnych dziedzinach życia i nauki;

3) ekonomia języka ${ }^{5}$ rozumiana tutaj jako najprostsza tendencja języka do wydajnego ,wydatkowania energii” w procesach komunikacyjnych.

Zapożyczenia funkcjonują $\mathrm{w}$ języku docelowym po przejściu różnych procesów adaptacyjnych, w których można wyróżnić kilka etapów. Ostateczna wersja adaptacji pojawia się po przejściu przez wspomniane etapy adaptacyjne dotyczące fonetyki, gramatyki, czy budowy wyrazu, tzw. podprocesy adaptacyjne ${ }^{6}$. Adaptacja może następować w kilku odrębnych procesach lub mogą one zachodzić równocześnie na poziomie różnych podsystemów języka, możemy wyróżnić między innymi:

1) język zapożyczający (B) adaptuje słowo pochodzące z języka (A) na wzór własnych struktur (może to dotyczyć systemu fonetycznego lub gramatycznego). Ta modyfikacja powoduje, że użytkownicy języka (B), do którego wchodzi zapożyczenie, chętniej używają elementu zapożyczonego. Nastąpiła bowiem domestykalizacja, dzięki której mogą się utożsamiać z danym elementem i przyjąć go jako element własnego języka / kultury. Procedura taka jest pojmowana jako częściowa modyfikacja. Ta opcja była popularna historycznie i dotyczyła np. akcentów, głosek etc. W zapożyczeniach z j. arabskiego nie dotyczyła ona słów związanych z nauką.

2) Zapożyczenia z języka (A) bez żadnej modyfikacji. Użytkownicy języka zapożyczającego (B) chcą pokazać swoje zdolności i kompetencje językowe oraz udowodnić, że są w stanie wymawiać i stosować reguły z języka źródłowego (A) zapożyczenia. Nazywamy to zapożyczeniem całkowitym (przejście struktury fonetycznej, gramatycznej etc. z języka (A) w całości do języka (B).

3) Zapożyczenie, w którym w jednym słowie następuje połączenie systemu głoskowego języka (A) i języka (B), np. arabski i hiszpański (zmiany dotyczące warstwy fonetycznej języka).

4) Zapożyczenia w postaci kalki językowej z języka (A) do języka (B) - wyrazowej lub frazeologicznej.

5) Zapożyczenia będące internacjonalizmami, hybrydami czy tzw. wtrętami (cytatami). ${ }^{7}$

\footnotetext{
${ }^{5}$ Por. tzw. zasady prostoty, ekonomii i elegancji: Chomsky (1995), (2000), (2005) oraz definicję stosunku zasady najmniejszego wysiłku do zasady dążenia do zrozumiałości: Lyons (1976: 107).

${ }^{6}$ Por. Oueslati (2021).

${ }^{7}$ Por. Mańczak-Wohlfeld (1995), Doroszewski (1938), Carstensen (1988), Maćkiewicz (1984).
} 
W badaniu zapożyczeń należy również uwzględnić fakt (braku) podatności różnych podsystemów języka na zapożyczenia, np. najbardziej podatnymi na zapożyczenia są podsystemy leksykalny i składniowy, a zapożyczenia w podsystemie głoskowym czy w morfemach wskazują na bardzo głęboki wpływ jednej kultury/języka na drugą, ponieważ są to podsystemy, do których zapożyczenia trudniej przechodzą. Dotyczy to systemów otwartych lub zamkniętych języka i różnego ich stopnia otwartości/zamkniętości. Przejście zapożyczeń do systemów zamkniętych języka jest trudniejsze i wymaga długotrwałego i wielowymiarowego kontaktu kultur i języków. Miała miejsce taka sytuacja np. w wypadku zapożyczeń z języka arabskiego w języku hiszpańskim. W tym miejscu należałoby podkreślić, że zapożyczenia są korzystne dla obu języków (A i B).

Badania słów zapożyczonych rozumiemy zatem jako badanie poszczególnych elementów leksykalnych pochodzących z języka (A) i zaadaptowanych do języka (B), funkcjonujących w tym języku w tym samym lub zmienionym (poszerzonym / zawężonym) obszarze znaczeniowym, fonetycznym, gramatycznym etc. Zapożyczenie traktujemy również jako efekt spotkania dwóch kultur i języków, uwzględniając fakt, że zapożyczenie z jednego języka (A) do drugiego (B) przechodzi proces adaptacji oraz integracji w systemie fonetycznym, gramatycznym i leksykalnym języka zapożyczającego.

Omawiając zapożyczenia z języka arabskiego, należy pamiętać o ich bardzo dużej liczbie i szerokim zasięgu (funkcjonują m.in. w j. tureckim, perskim, malajskim, indonezyjskim, hindi, portugalskim, włoskim czy francuskim). W niektórych językach są tak liczne, że dochodzą do kilku tysięcy (np. malajski, indonezyjski, turecki). Oczywiście zapożyczenia $\mathrm{z} \mathrm{j}$. arabskiego, $\mathrm{w}$ tym $\mathrm{w}$ podanych powyżej językach, dotyczą głównie sfery leksykalnej języka i jego różnych kategorii i pól semantycznych, występują w słownictwie związanym z dziedzinami takimi, jak medycyna, architektura, prawo, religia. W klasycznych tureckim, indonezyjskim, perskim i malajskim stosowano również alfabet arabski. W językach europejskich najwięcej zapożyczeń $\mathrm{z}$ j. arabskiego występuje $\mathrm{w} \mathrm{j}$. hiszpańskim i dotyczy przede wszystkim obszaru architektury, rolnictwa, kuchni, literatury czy medycyny.

Nie zapominamy, że $\mathrm{w}$ j. arabskim występują też zapożyczenia z innych języków, np. europejskich, takich jak francuski, włoski czy hiszpański. Ten aspekt zapożyczeń nie stanowi jednak obszaru zainteresowań autorek w niniejszym opracowaniu.

Głównym celem badawczym niniejszego opracowania jest ukazanie zasięgu integracji wybranego słownictwa $\mathrm{w}$ systemie leksykalnym języka hiszpańskiego (funkcjonowanie $\mathrm{w}$ tekście pisemnym / ustnym). Zostaną przedstawione wybrane przykłady obrazujące zakres integracji i asymilacji wskazanego słownictwa w podsystemie leksykalnym castellano. Ze względu na fakt, iż język hiszpański jest językiem policentrycznym, o wielu standardach, należy również podkreślić, że w niniejszym opracowaniu zainteresowania badawcze skupiają się na wariancie j. hiszpańskiego obejmującego swym zasięgiem obszar współczesnej Hiszpanii. 


\section{Kontakty hiszpańsko-arabskie: wybrane aspekty}

\subsection{Zarys tla historycznego}

W 711 mieszkańcy Afryki Północnej, tzn. Arabowie i Berberowie dotarli do Płw. Iberyjskiego (obecnej Hiszpanii i Portugalii) i przez 800 lat opanowali prawie cały Płw. Iberyjski, co spowodowało, że kultura arabska (z Pn. Afryki) jest silnie obecna do dziś w kulturze i języku hiszpańskim. Nazywali się z arabskiego mawaribe (ludzie, którzy mieszkają w Maroku, Tunezji i Algierii; ludzie z Afryki Północnej). Pomimo że panowanie Arabów na Płw. Iberyjskim zakończyło się w roku 1492, nie oznaczało to jednak końca kontaktów obu kultur (hiszpańskiej i arabskiej) i języków (zapożyczeń pomiędzy oboma językami). Kontynuacja kontaktów kulturowojęzykowych trwa z powodu migracji ludności arabskiej (magrebu) do Hiszpanii i obecności hiszpańskiej na kontynencie afrykańskim (Ceuta i Melilla) oraz licznych kontaktów handlowych z Marokiem. Wpływ kultury arabskiej można zobaczyć między innymi w architekturze miast (głównie południe Hiszpanii) i nazewnictwie miejscowości i elementów miejskich oraz w nazwach geograficznych, toponimach, urbanonimach etc.

Wojska muzułmańskie przybyły na Półwysep Iberyjski, aby go podbić i zasiedlić. Celem podboju było opanowanie tych ziem i wcielenie ich do Dar al-Islam. Arabowie podbili między innymi: Kordobę i Granadę, a także ówczesną stolicę Toledo. W kolejnych latach doszło do następnych podbojów, wskutek czego muzułmanie opanowali prawie cały teren Półwyspu Iberyjskiego. Podbój nie był trudny ze względu na nikły opór chrześcijan zamieszkujących półwysep. Przejęte tereny zostały nazwane Al-Andalus. ${ }^{8}$ Tereny niepodbite, pozostające poza władzą arabską to obszar zamieszkały przez Basków, Asturia (ostatecznie wyzwolona od najeźdźców) oraz Galicja (od 740 roku). Kolejne lata przyniosły wiele zmian. Pomimo konfliktów wewnętrznych w Al-Andalus (konflikty pomiędzy różnymi rodami arabskimi) oraz częstych zmian rządzących podbitymi terenami władza arabska na Półwyspie Iberyjskim umacniała się. Jednym z wyróżniających się przywódców arabskich był Abd ar Rahman, który w roku 773 zerwał stosunki z Abbasydami, ogłosił się niezależnym emirem i stworzył silne i sprawne państwo arabskie na terenach obecnej Hiszpanii.

W 912 roku nowy władca, Abd al-Rahman III, założył Kalifat Kordoby. W tym czasie rozpoczął się okres największego rozkwitu kultury arabskiej na Półwyspie Iberyjskim. W roku 929 Abd al-Rahman III ogłosił się kalifem - „Amir al-muminin” [z arab. Amīr Al-Mu'minīn, co oznacza przywódce wierzacych]. Na czasy rządów kalifa Rahmana III, określanego mianem najlepszego władcy arabskiej Hiszpanii,

\footnotetext{
${ }^{8}$ Por. np. Tuñón de Lara, Valdeón Baruque, Domínguez Ortiz (1997: 96).
} 
przypada rozkwit i lata świetności Kalifatu Kordoby. Rozwinął się wówczas i umocnił handel z Sudanem na północy Afryki oraz z Imperium Bizantyjskim w basenie Morza Śródziemnego. Dochody pozwoliły na rozwój i wprowadzenie zmian w zakresie polityki, ekonomii, wojskowości, co z kolei przełożyło się na rozwój gospodarczy i rozkwit dziedzin takich, jak kultura, sztuka czy nauka na tych obszarach. Miało to niebagatelny wpływ na wzajemne przenikanie się kultur wspótistniejących na terenie Al-Andalus.

Kolejne lata panowania arabskiego na Półwyspie Iberyjskim przyniosły dalsze zmiany, a spadkobiercom Abd al-Rahama III udało się utrzymać jedność państwową i prowadzić podboje. Koniec kalifatu nastąpił dopiero po śmierci Hisama II, co doprowadziło do powstania w Al-Andalus, w latach 1031-1492, podziału politycznoadministracyjnego określanego mianem taifas (reinos de taifas) stanowiących odrębne jednostki polityczne. Możemy mówić o istnieniu trzydziestu dziewięciu niezależnych królestw konkurujących ze sobą o władzę i wpływy. Ich władcy zabiegali o wsparcie i pomoc ludów muzułmańskich z północnej Afryki (Almorawidów pochodzenia berberyjskiego i Almohadów), które broniąc islamu, wprowadziły prześladowania mozarabów (mozárabes), chrześcijan mówiących po arabsku i zamieszkujących tereny Al-Andalus, zmuszając ich do ucieczki do sąsiednich królestw chrześcijańskich. W kolejnych latach, korzystając z braku jedności po upadku Kalifatu Kordoby i wzajemnej rywalizacji między władcami poszczególnych taifas, chrześcijanie rozpoczęli rekonkwistę utraconych ziem. W roku 1492, za czasów panowania Królów Katolickich: Izabeli (Izabeli I Kastylijskiej) i Ferdynanda (Ferdynanda II Aragońskiego) upadło ostatnie królestwo arabskie na terenie Półwyspu Iberyjskiego - Granada. Tym samym kończy się ośmiowieczne panowanie muzułmanów na terenie półwyspu i władzę przejmują królowie chrześcijańscy.

$\mathrm{Na}$ terenie Al-Andalus występowało wiele różnic społecznych i współistniały trzy dominujące kultury: muzułmańska, chrześcijańska oraz żydowska. Pomimo różnic kulturowych, religijnych i skomplikowanego systemu administracyjno-społecznego przedstawiciele wspomnianych kultur w początkach panowania arabskiego współistnieli pokojowo, tworząc spójne społeczeństwo. Za czasów Al-Andalus na terenach półwyspu została wprowadzona reforma rolna. Arabowie, przybywając na półwysep, przywieźli ze sobą nowe rośliny i sposoby uprawy, powodując wzrost produkcji żywności, a co za tym idzie - populacji. Rozwinęło się rzemiosło oraz handel. Kordoba jako najważniejsze miasto Al-Andalus stała się głównym ośrodkiem handlowym, naukowym i kulturalnym. Arabowie mieli wpływ na architekturę miast - powstało wiele budowli w stylu mudejar (m.in. meczet w Kordobie), przyczynili się do rozwoju regionu oraz szeroko pojętej kultury. Uczestniczyli w rozwoju kraju i kształtowaniu się wielu dziedzin życia, nauki, sztuki, co znajduje odzwierciedlenie również w samym języku hiszpańskim, jego strukturze i leksyce. 


\subsection{Wybrane przykłady zapożyczeń z j. arabskiego do języka hiszpańskiego}

W ośrodkach naukowych Hiszpanii prowadzone są studia i badania (synchroniczne i diachroniczne) dotyczące języka i kultury arabskiej oraz ich wpływu na język i kulturę Hiszpanii. Wielu językoznawców hiszpańskich potwierdza wpływ j. arabskiego na j. hiszpański. Wg Rafaela Lapesy ${ }^{9}$ w j. hiszpańskim istniało ok. 4000 słów pochodzenia arabskiego, część słów przeszła do hiszpańskiego w niezmienionej formie (minimalne modyfikacje), a część (większa) uległa modyfikacjom m.in. ze względu na:

1) preferencje językowe użytkowników j. hiszpańskiego;

2) ze względu na brak w systemie głoskowym j. hiszpańskiego głosek istniejących $\mathrm{w} \mathrm{j}$. arabskim - stąd wymowa zbliżona fonetycznie do j. arabskiego, ale nie identyczna.

Możemy również mówić o zapożyczeniach bezpośrednich lub pośrednich. Niektóre słowa pochodzenia arabskiego przeszły do języka hiszpańskiego poprzez inne języki (m.in. turecki, włoski, francuski, łacinę, np. wyraz café jest pochodzenia arabskiego (arabski klas. qahwah), ale przeszedł do j. hiszpańskiego z j. włoskiego (caffe), a do włoskiego z tureckiego (kahve) $R A E^{10}$ ). Jednak grupa zapożyczeń bezpośrednich jest zdecydowanie większa i stanowi trzon badań dotyczących arabizmów $\mathrm{w} \mathrm{j}$. hiszpańskim. Zapożyczenie $\mathrm{z}$ arabskiego do $\mathrm{j}$. hiszpańskiego może uwzględniać tylko jedno ze znaczeń danego wyrazu występujące $w$ j. arabskim i jego dialektach (np. café - qahwah oznacza „kawę” (napój), ale w niektórych dialektach może oznaczać też „kawiarnię” (miejsce). A w j. hiszpańskim występuje jako znaczenie prymarne - „kawa” (napój)). W zależności od podejścia badawczego i metodologii - różni badacze wskazują na różną liczbę zapożyczeń z j. arabskiego do j. hiszpańskiego. Dotyczy to obliczeń poszczególnych słów lub słów i ich derywatów. W wypadku drugiego podejścia badawczego liczba wspomnianych zapożyczeń może sięgać $8 \%$.

Należy podkreślić, że zapożyczenia $\mathrm{z}$ j. arabskiego do języka hiszpańskiego przeszły z języka arabskiego ustnego (dialekty, warianty) oraz pisemnego (arab. klas.). Skutkuje to brakiem standaryzacji i w praktyce często oznacza przejście wersji zgodnej z wymową, a nie z zapisem graficznym wyrazu. Na zmiany znaczeń w języku docelowym zapożyczenia ma też wpływ fakt, że w wielu wypadkach przejście nastąpiło z dialektu, który posługuje się szerszym (lub węższym) polem znaczeniowym (semantycznym) w stosunku do klasycznego języka arabskiego - co widoczne jest w zapożyczeniach występujących w j. hiszpańskim. Stąd też trudność badania polega m.in. na stwierdzeniu, $z$ którego wariantu $\mathrm{j}$. arabskiego pochodzi dane zapożyczenie i jest to element, na który należy zwrócić uwagę w trakcie analiz.

\footnotetext{
${ }^{9}$ Lapesa (1981).

${ }^{10} \mathrm{https} / / /$ dle.rae.es/caf\%C3\%A9?m=form [data dostępu: 1.06 .2021$]$.
} 
Użytkownicy języka hiszpańskiego stosują w swoim życiu codziennym arabizmy, często nie zdając sobie z tego sprawy - co wskazuje na głęboki wpływ i zasięg arabizmów w j. hiszpańskim. Przedstawione poniżej nazwy, toponimy czy urbanonimy wskazują na głęboki zasięg wpływów arabskich na rzeczywistość, w tym językową, Półwyspu Iberyjskiego i są najczęściej wskazywanymi zapożyczeniami $\mathrm{z} \mathrm{j}$. arabskiego w języku hiszpańskim. W praktyce użytkownicy języka hiszpańskiego (mozárabes) często na co dzień posługiwali się j. arabskim - co oznaczało łatwe i niezauważalne przejście do j. hiszpańskiego słów, konstrukcji gramatycznych czy budowy niektórych form literackich (np. bajek). Ponadto język arabski jest widoczny w imionach i nazwach własnych, rzadko w czasownikach, przymiotnikach i przysłówkach oraz systemie głoskowym. Najczęstsze zapożyczenia dotyczą jednak podsystemu leksykalnego języka hiszpańskiego.

Ilustracją wspomnianych zapożyczeń są przytoczone poniżej przykłady, z racji swego charakteru podzielone na trzy grupy - toponimy, wyrazy związane z życiem codziennym oraz zapożyczenia leksykalno-kulturowe. Potwierdzają one głęboki, dotyczący wielu podsystemów języka i języków specjalistycznych, wpływ kultury i języka arabskiego na kulturę oraz język hiszpański. Pierwsza część przykładów dotycząca toponimów - została przytoczona wg następującego schematu: nazwa $\mathrm{w} \mathrm{j}$. hiszpańskim, pochodzenie $\mathrm{z} \mathrm{j}$. arabskiego oraz znaczenie dosłowne $\mathrm{w} \mathrm{j}$. arabskim. Transliteracja poszczególnych słów pochodzi z dostępnych opracowań i artykułów dotyczących arabizmów, a nie ze słownika $D R A E$, wybrano najczęściej wskazywane formy zapisów.

i) Nazwy geograficzne:

Gibraltar [z arab. jabal Tariq - „góra Tariq"]; Algeciras [z arab. al-jazeera al-khadra - „zielona wyspa"]; wiele toponimów zawiera człon guada [z arab. wadi - „rzeka” / „dolina”], stąd przykłady takie jak: Guadalajara [z arab. wadi al-hijarah - „rzeka / dolina kamieni”]; Guadalcazar [z arab. wadi al-qasr „rzeka / dolina zamku”]; Guadalaviar [z arab. wadi al-abyad - „biała rzeka”]; Guadalquivir [z arab. wadi al-kabir - ,wielka rzeka”].

ii) Nazwy miast:

Albacete [z arab. al-basit - „prosty /płaski”]; Albufera [al-buhayrah - ,, małe jezioro”]; Alcalá [z arab. al-qal ${ }^{c}$ ah - „fort”]; Alpujarra [z arab. al-bashurah „bastion lub wiadomość"]; Alcantara [z arab. al-qantarah - „most”]; Almería [z arab. czasownik raa - „oglądać, kontrolować, obserwować” lub z arab. miraat - „lustro"]; Benicasim [z arab. Bani Qasim - ,synowie Qasima"]; Calatayud [z arab. qal cat Ayyub - „fort Ayyub"]; Calata Azor [z arab. qal c at an-nusur „fort orła"]; Madrid [1. dwa człony różnego pochodzenia: $\mathrm{z}$ arab. mażra „miejsce gdzie płynie woda / koryto rzeki” i z łac. itu „dużo wody”; 2. z arab. majri - „rodzaj bryzy”]; Medinaceli [z arab. madinat Salim - „miasto Salima”]; Murcia [z arab. misriyah - „Egipcjanka”]; Tarifa [z arab. Tarik - ,pierwszy mu- 
zułmanin, który pojawił się w Hiszpanii']; Vega [z arab. buq ${ }^{c} a h$ - ,pole / miejsce”]; Valladolid [z arab. balad al-Walid - „miasto Walida”].

iii) Nazwy ulic:

La Rambla [z arab. arramla - ,piasek z morza"]; Sequia (kat. Carrer de la Sèquia) [z arab. assakja - „tam gdzie płynie woda”, Maroko: darbe assekja „zaułek"].

Poza licznymi przykładami toponimów wpływ języka arabskiego jest też widoczny w słownictwie związanym z życiem codziennym, rolnictwem, nazwami przedmiotów codziennego użytku, zawodów etc., jak również w popularnych zwrotach i pozdrowieniach oddających wpływ samej kultury na język i kulturę hiszpańską. Wiele opracowań podaje część słów jako pochodzące $\mathrm{z}$ j. arabskiego, jednak w niektórych wypadkach słownik (Diccionario de la Lengua Española, $R A E^{11}$ ) tego nie potwierdza lub wskazuje wyłącznie na prawdopodobieństwo pochodzenia, dlatego ze względu na naturę niniejszego badania autorki zdecydowały się przytaczać wyłącznie przykłady wyrazów, których arabskie pochodzenie jest potwierdzone przez słownik $R A E$. Podobny problem dotyczy różnic $\mathrm{w}$ transliteracji lub transkrypcji słów arabskich, które przeszły jako zapożyczenie do języka hiszpańskiego w różnych źródłach przyjmowano różne formy zapisu słów arabskich - dlatego również w tym wypadku autorki korzystały z form wskazanych przez Diccionario

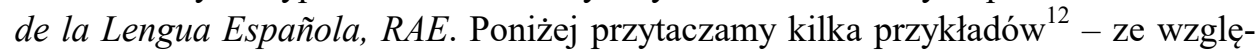
dów redakcyjnych przedstawionych w kolejności alfabetycznej wg wzoru: zapożyczenie funkcjonujące $\mathrm{w} \mathrm{j}$. hiszpańskim, [pochodzenie] i thumaczenie zapożyczenia funkcjonującego $\mathrm{w} \mathrm{j}$. hiszpańskim na j. polski.

aceite $[\mathrm{z}$ arab. hiszp. azzáyt, to $\mathrm{z}$ arab. klas. azzayt, a to $\mathrm{z}$ aram. zaytā] - „olej”; aceituna [z arab. hiszp. azzaytúna, to $\mathrm{z}$ arab. klas. zaytūnah, a to $\mathrm{z}$ aram. zaytūnā, zdrobninie od zaytā] - „oliwka”; adobe [z arab. hiszp. atțúb, to z arab. klas. $t \bar{u} b$, to od egip. $\underline{d} b t]$ - „cegła suszona na słońcu”; alacena $[\mathrm{z}$ arab. hiszp.. alhazána, a to $\mathrm{z}$ arab. klas. hizānah.] - „kredens”; alberca [z arab. hiszp. albirka, i to z arab. klas. birkah] - „basen / sadzawka”; albóndiga [z arab. hiszp.

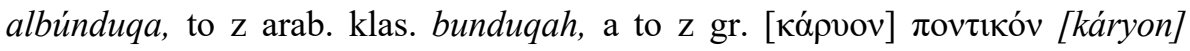
pontikón '[orzech], podobieństwo formy] - „klopsik”; alcachofa [z arab. hiszp. alharšúf[a], to z arab. huršūff[ah], a to prawdopodobnie z pelvi (pehlevi) hār $\check{c} \bar{o} b$ ] - „karczoch”; alcalde [z arab. hiszp. alqádil, to z arab. klas. qāḍ̄ ] - „burmistrz”, alcaldía - „biuro burmistrza”; alcantarillas [zdrobnienie od hiszp. alcántara, a to $\mathrm{z}$ arab. hiszp. alqánțara, to $\mathrm{z}$ arab. klas. qantarah, a to prawdo-

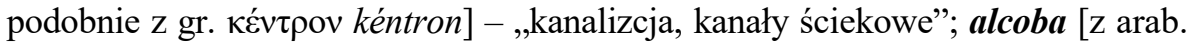
hiszp. alqúbba, to z arab. klas. qubbah, a to z pelvi (pehlevi) gumbad] - „sypial-

${ }^{11}$ REAL ACADEMIA ESPAÑOLA: Diccionario de la lengua española, 23 edycja [wersja 23.4 online], https://dle.rae.es [data dostępu: maj-czerwiec 2021].

${ }^{12}$ Ibidem. 
nia, alkowa”; alcohol [z arab. hiszp. kuhúl, to z arab. klas. kuhl] - „alkohol”; al$\boldsymbol{d a b a}$ [z arab. hiszp. add dabba, to z arab. klas. dabbah] - „kołatka”; aldea [z arab. hiszp. addáy'a, to z arab. klas. day'ah] - „wioska”; alfombra [1. z arab. hiszp. alhánbal, to z arab. klas. hanbal; 2. z arab. hiszp. alhúmra, to z arab. klas. humrah] - „dywan”; algodón [z arab. hiszp. alquțun, to z arab. klas. quṭn] - „,bawełna”; almacén [z arab. hiszp. almahzzán, to z arab. klas. mahzzan]- „magazyn, sklep”; almohada [z arab. hiszp. almuhádda, to z arab. klas. mihhaddah] - „poduszka"; alubia [z arab. hiszp. allúbya, to z arab. klas. lúbiya ', a to z pers. $L u$ beyā] - „fasola”; arroz [z arab. hiszp. arráwz, to $\mathrm{z}$ arab. klas. àruz[z] lub $\operatorname{aruz}[z]$, to $\mathrm{z}$ gr. ópvढ $\alpha$ óryza, a to $\mathrm{z}$ tam. (tamil) arici] - „ryż”; atún [z arab. hiszp. attún, to $\mathrm{z}$ arab. klas. tunn, a to łac. thunnus, to z gr. Өv́vvos thýnnos] „tuńczyk”; azafrán [z arab. hiszp. azza'farán, to z arab. klas. za'farān] - „szafran”; azar [z arab. hiszp. azzahr, to z arab. zahr] - ,przypadek / hazard”; azotea [z arab. hiszp. assutáy ha, zdrobnienie od sáth, to z arab. klas. saṭh] - „taras (na dachu) / dach"; azúcar [z arab. hiszp. assúkkar, to z arab. klas. sukkar, to z gr.

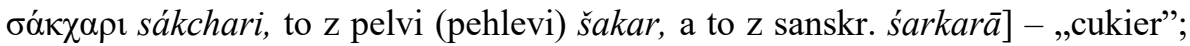
azucena [z arab. hiszp. asussána, to $\mathrm{z}$ arab. klas. sūsanah, a to z pelvi (pehlevi) sōsan] - „lilie”; azul [z arab. prawdopodobnie alternacja $\mathrm{z}$ arab. hiszp. lazawárd, to $\mathrm{z}$ arab. lāzaward, to $\mathrm{z}$ pers. lağvard lub lažvard, a to $\mathrm{z}$ sanskr. rājāvarta] - „niebieski”; azulejo [z arab. hiszp. azzuláyğ[a]] - „kafelek / płytka"; barrio [z arab. hiszp. bárri, to z arab. klas. barrī] - „dzielnica”; berenjena [z arab. hiszp. badinğána, to $\mathrm{z}$ arab. klas. bādinğḡanah, a to z pers. bātingān] „bakłażan”; café [z wł. caffe, to z tur. kahve, a to z ar. klas. qahwa] - „kawa”; espinaca [z arab. hiszp. isbináh [a], to $\mathrm{z}$ arab. isbānah lub isfānahl, a to z pers. espenāh ] - „szpinak”]; fulano [z arab hiszp. fulán, to $\mathrm{z}$ arab. klas. fulān, a to prawdopodobnie z egip. $p w r n$ ] - „pewien człowiek, iksiński”; gazpacho [prawdopodobnie z arab. hiszp. gazpáčo, to z gr. $\gamma \alpha \zeta o \varphi v \lambda \alpha ́ \kappa ı$ gazophylákion] - ,zu-

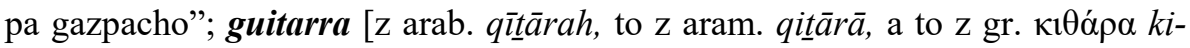
thára] - „gitara"; jarabe [z arab. hiszp. šaráb, to z arab. klas. šarāb] - „syrop”; jarra [z arab. hiszp. ğárra, to $\mathrm{z}$ arab. klas. ğarrah] - „dzban”; limón [z arab. hiszp. la [y]mún, to $\mathrm{z}$ arab. laymūn, to $\mathrm{z}$ pers. limu, a to z sanskr. nimbu] - „,ytryna"; mudéjar [z arab. hiszp. mudáğğan, to $\mathrm{z}$ arab. klas. mudağğan] - obecnie styl $\mathrm{w}$ architekturze; naranja [z arab. hiszp. naranğa, to $\mathrm{z}$ arab. nāranğ, to $\mathrm{z}$ pers. nārang, a to z sanskr. nāranga] - ,pomarańcza / kolor pomarańczowy”; quintal [z arab. hiszp. qințár, to $\mathrm{z}$ syr. qanțīa $\bar{a}$, a to $\mathrm{z}$ łac. centenarium] - „kwintal"; sofá [z fr. sofa, to z pers. soffe, a to z ar. klas. al-șuffah] - „,sofa”; tabique [z arab. hiszp. tašbik, to z arab. klas. tašbīk] - „ścianka działowa”; tambor [prawdopodobnie z arab. hiszp. țabbūl] - „bęben”; tarea [z arab. țarihha, to $\mathrm{z}$ arab. klas. $\{t r h\}]$ - „zadanie, praca”; tarifa [z arab. hiszp. ta'rifa, to $\mathrm{z}$ arab. klas. ta'rīfah, z ta 'rîf] - „taryfa”; taza [z arab. hiszp. tássa, to z arab. țassah lub arab. klas. țast, a to z pers. tašt] - „filiżanka”; zagal [z arab. hiszp. zağáll[l] lub 
$\mathrm{z}$ arab. klas. $z u \bar{g} l \bar{u} l]$ - „chłopak”; zanahoria [z arab. hiszp. safunnárya, to

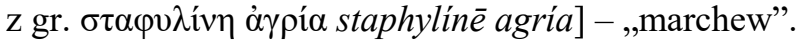

Jak już zostało wspomniane do języka hiszpańskiego, a także zwyczajów społecznych przeszły też niektóre zachowania kulturowe - pod postacią utartych zwrotów, które możemy rozpatrywać jako „kalki kulturowe”, rozumiane jako dosłowne tłumaczenie całości lub części zwrotu / powiedzenia arabskiego funkcjonującego w określony sposób i w określonych sytuacjach w kulturze arabskiej i przeniesione pod postacią thumaczenia do języka i kultury hiszpańskiej wraz z funkcjonalnością i uzusem stosowania $w$ sytuacjach komunikacyjnych. Poniżej kilka wybranych przykładów z tłumaczeniem znaczenia arabskiego w nawiasie oraz z j. hiszpańskiego poza nawiasem:

¡Hasta la vista! [hybryda: z arab. hatta - „do, aż do" i z hiszp. la vista „widok”] - „Do zobaczenia!”; ;Si Dios quiere! [z arab. Insha' Allah! - „Jeśli taka wola boża”] - „Jeśli Bóg zechce”; ;Ojalá! [z arab. Insha’ Allah! - „oby”] - „oby, żeby”; Dios le ayude [Allah ya ctik - „Niech Bóg Cię wspiera”] - „Niech Bóg Ci pomoże”; Esta es su casa [z arab. Hadha baytukum - „Czuj się jak u siebie w domu”] - „Czuj się jak u siebie w domu”; Vaya por Dios [z arab. Hadha iradat Allah - „Bóg tak chciał”] - „Z Bogiem”.

Podane przykłady miały na celu zobrazowanie, w jaki sposób i jak silnie kultura arabska oddziaływała na przestrzeni historii Półwyspu Iberyjskiego (dawniej i dziś) na język hiszpański. Powyższe przykłady ukazują perspektywę zakorzenienia i zasięgu arabizmów w języku hiszpańskim występujących w różnych tekstach współczesnych, z różnymi modyfikacjami znaczeniowymi. Wspomniane wpływy nie dotyczą wyłącznie przejętych struktur językowych, lecz również obyczajów i zachowań kulturowych przeniesionych i funkcjonujących w języku i kulturze hiszpańskiej w dosłownym tłumaczeniu z języka arabskiego, co jest szczególnie widoczne na przykładzie przytoczonych zwrotów.

\section{Krótka historia badań nad zapożyczeniami z języka arabskiego do języka hiszpańskiego}

Badania nad zapożyczeniami z języka arabskiego na język hiszpański mają długą historię zarówno jako badania ukierunkowane na same arabizmy, jak i badania ogólne, w których jako jeden z nurtów badawczych pojawiają się analizy ww. zapożyczeń. Wpisują się one w szeroki trend badań nad wpływem języka i kultury arabskiej na języki romańskie. Badaczy interesują również wzajemne relacje łaciny i języka arabskiego, w tym wariantu z Al-Andalus.

Nie sposób w niniejszym opracowaniu wspomnieć o wszystkich prowadzonych badaniach dotyczących arabizmów i zapożyczeń z j. arabskiego (różnych jego wariantów) do języków romańskich, w tym do j. hiszpańskiego. Ze względu na ogrom- 
ny obszar badań oraz na charakter analizy prowadzonej w niniejszym opracowaniu autorki skupiły się wyłącznie na wskazaniu głównych kierunków powstających prac i prowadzonych poszukiwań, które w większości analizują zasoby leksykalne zapożyczeń. Przytoczone przykłady ograniczone zostały do prac powstających w języku hiszpańskim, jednak prace na ten temat powstają w różnych ośrodkach badawczych (głównie w obrębie jednostek dysponujących filologiami hiszpańskimi /iberyjskimi, iberoamerykańskimi czy arabskimi) i w różnych językach (arabskim, francuskim, niemieckim, włoskim, angielskim etc.). Badania $\mathrm{w} \mathrm{j}$. arabskim skupiają się na aspektach historycznych i mają charakter opisowy. W języku tym powstaje niewiele prac o charakterze językoznawczym, a ich autorzy powołują się na wyniki badań przedstawione przez hispanistów i brak w nich autonomicznej analizy językoznawczej. Polscy badacze przywołują zagadnienia zapożyczeń z j. arabskiego w kontekście szerszych badań historyczno-językoznawczych. $\mathrm{W} \mathrm{j}$. polskim powstają również prace dotyczące wpływów arabskich na j. polski. ${ }^{13}$ Jednak wśród polskich naukowców arabizmy nie są tak popularnym kierunkiem badań, jak np. w ośrodkach akademickich w Hiszpanii.

Różne opracowania przedstawiają badania bezpośrednie i pośrednie nad arabizmami (np. przy opracowaniu słowników języka hiszpańskiego - opisy poszczególnych haseł zawierają również pochodzenie danego słowa, w tym arabskie - wskazując tym samym listę arabizmów $\left.{ }^{14}\right)$. W badaniach nad zapożyczeniami możemy wyróżnić dwa dominujące kierunki: literaturoznawczy - koncentrujący się na analizie tekstów źródłowych pod kątem zapożyczeń z arabskiego oraz językoznawczy, w dużej mierze skupiający się na wielopłaszczyznowych badaniach nad leksyką. Analizy te dotyczą zarówno zapożyczeń bezpośrednich z języka arabskiego, jak również przejść, które nie są bezpośrednie i odbywają się za pośrednictwem trzeciego języka. Powstające opracowania uwzględniają m.in. chronologię, źródła i sposób przejścia zapożyczeń, różne obszary geograficzne, pola semantyczne czy etymologię.

Językoznawcy hiszpańscy, zajmujący się wpływem języka arabskiego na język hiszpański, w swoich pracach skupiają się głównie na badaniach nad zapożyczeniami uwzględniającymi fonetykę, gramatykę i leksykę z podziałem na poszczególne dziedziny. Główny punkt referencyjny stanowią słowniki - podające stosowne odniesienia do pochodzenia, użycia, definicji etc. oraz historyczne materiały źródłowe (zarówno teksty użytkowe, jak i literackie). Jak już zostało wspomniane w dalszej części niniejszego rozdziału skupimy się na materiałach w języku hiszpańskim, ponieważ w tym właśnie języku powstaje najwięcej opracowań, które tworzą szeroką i spójną panoramę badań nad arabizmami w językach romańskich, w tym w j. hiszpańskim. Autorzy przytaczanych prac skupiają się na ogólnej panoramie

\footnotetext{
${ }^{13}$ Por. Szałek (2013), Turek (2001), oraz recenzję Zaborskiego (2002).

${ }^{14}$ Por. np. Real Academia Española: Diccionario de la lengua española, 23 edycja [wersja 23.4 online], $<$ https://dle.rae.es $>$
} 
wpływów i wzajemnego oddziaływania kultur i języków obecnych na Półwyspie Iberyjskim oraz na poszczególnych aspektach tego oddziaływania, m.in. takich, jak wpływ na konkretne warianty j. hiszpańskiego, inne języki, którymi posługuje się ludność zamieszkująca Półwysep Iberyjski, interferencje z łaciną etc. Powstające prace można podzielić ze względu na ich zasięg badawczy, materiały źródłowe czy podział na badania zależne od płaszczyzn językowych, którymi się zajmują. Prowadzone badania są liczne i różnorodne, można wyróżnić, m.in. następujące rodzaje powstających prac: książki dotyczące historii języka hiszpańskiego, prace zbiorowe, monografie, artykuły oraz słowniki ogólne i tematyczne dotyczące arabizmów czy prace doktorskie.

Niniejszy przegląd badań należałoby zacząć od prac ogólnych, traktujących o historii języka hiszpańskiego, w których uwzględniono wpływ języka arabskiego na język hiszpański wraz z innymi uwarunkowaniami historycznymi i modyfikacjami, jakim podlegał język hiszpański na przestrzeni wieków. Jednym z bardziej znanych opracowań dotyczących historii języka hiszpańskiego jest praca autorstwa Rafaela Cano Aguilara ${ }^{15}$ El español a través de los tiempos. Autor przedstawia między innymi wpływ języków okresu preromańskiego oraz języka arabskiego na konfigurację języka hiszpańskiego jako autonomicznego systemu językowego. W części o pracach ogólnych dotyczących historii języka hiszpańskiego należałoby wspomnieć również o takich dziełach, jak Historia de la lengua española czy Estudios de historia lingüistica española Rafaela Lapesy ${ }^{16}$.

Kolejne pozycje bibliograficzne dotyczące zapożyczeń z j. arabskiego do hiszpańskiego to opracowania zbiorowe historii języka hiszpańskiego. Jednym z takich opracowań jest Historia de la lengua española (2004) ${ }^{17}$. Pozycja ta jest podzielona na działy obrazujące zmiany historyczne zachodzące w języku hiszpańskim, dotyczące m.in. Hiszpanii preromańskiej, łaciny na Półwyspie Iberyjskim, arabskiego na Półwyspie Iberyjskim, ukonstytuowania się języków romańskich na Płw. Iberyjskim, kastylijskiego w wieku XIII, zmian językowych w wiekach średnich czy współczesnej hiszpańszczyzny. Jednym z rozdziałów jest El elemento árabe en la historia lingüistica peninsular: Actuación directa e indirecta. Los arabismos en los romances peninsulares (en especial, en castellano) autorstwa arabisty i leksykografa hiszpańskiego, członka RAE (od 2017) - Federico Corriente Córdoby. Traktuje on o historycznych wpływach arabskich (pośrednich i bezpośrednich) na języki romańskie, ze szczególnym uwzględnieniem języka hiszpańskiego. Federico Corriente to również autor licznych monografii i artykułów dotyczących arabizmów (dialektologia arabska, szczególnie andalusi) w językach romańskich (w tym w różnych wariantach języka hiszpańskiego), poświęconych toponimom pochodzenia arabskiego,

\footnotetext{
${ }^{15}$ Cano Aguilar (1988).

${ }^{16}$ Lapesa (1985).

${ }^{17}$ Cano (coord.) (2004).
} 
leksykografii arabskiej w Hiszpanii oraz słowników arabizmów ${ }^{18}$. Jest to autor, który swymi pracami wszechstronnie wpisuje się w nurt badań nad wpływami kultury i języka arabskiego (różnych jego wariantów) na kulturę i język hiszpański.

Zapożyczenia z języka arabskiego do języków obecnych na Płw. Iberyjskim przeszły historycznie (wieki średnie) głównie w formie ustnej dzięki obecności arabskiej na terenie ówczesnej Hiszpanii poprzez wzajemne relacje społeczne (mozárabes, mudéjares, moriscos) oraz pisemne teksty literackie, rolnicze, medyczne, teksty użytkowe czy thumaczenia. Relacje te, formy, drogi przejścia do j. romańskich (w tym j. hiszpańskiego) oraz sposób kształtowania się arabizmów w językach docelowych to kolejne obszary badań literaturoznawczych i językoznawczych będące przedmiotem licznych opracowań monograficznych ${ }^{19}$.

W badaniach nad arabizmami można również wydzielić nurt badań nad wzajemnymi wpływami łaciny i różnych wariantów języka arabskiego (w tym z Al-Andalus), które w późniejszych wiekach przekładają się też na wpływ na języki romańskie, co odzwierciedlają m.in. monografie takie, jak: Arabic as a minoritary language, Jonathan Owens ${ }^{20}$ czy prace wspomnianego już Federico Corriente.

Relacje języka arabskiego z językami romańskimi są też tematem artykułów, np. „Palabras aventureras. Hispanismos olvidados, escondidos en hablas árabes de Marruecos” Simón Lévy ${ }^{21}$. Należy jednak podkreślić, że badania dotyczące zapożyczeń z języka arabskiego do różnych standardów języka hiszpańskiego - biorąc pod uwagę policentryczność języka hiszpańskiego i jego zasięg geograficzny - stanowią ogromny i nadal wymagający pogłębionych analiz porównawczych obszar poszukiwań, szczególnie w kierunku stopnia zintegrowania, użycia oraz pól semantycznych poszczególnych arabizmów. W tym miejscu warto przytoczyć artykuł Any Ruth Vidal-Luengo, Vitalidad diacrónica y sincrónica de arabismos léxicos en el español atlántico: Madeira, Canarias, América ${ }^{22}$, w którym ukazany został wpływ j. arabskiego na poszczególne płaszczyzny języka hiszpańskiego, z uwzględnieniem porównania wskazanych w tytule obszarów geograficznych.

Wielu autorów skupia się również na badaniach toponimów (urbanonimów, mikrotoponimów, hydronimów etc.) - jednym z bardziej znanych opracowań jest wystąpienie Jaime Olivera Asína zatytułowane En torno a los orígenes de Castilla. Su toponimia en relación con los árabes y los beréberes ${ }^{23}$, w którym autor wskazywał

\footnotetext{
${ }^{18}$ Por.: Corriente Córdoba (1992), (2000), (1999), (1998), (1996), (1981-1982), (1997a-c), (2008), (2003).

${ }^{19}$ Por. między innymi: Galmés de Fuentes, Sánchez Álvarez, Vespertino Rodríguez, Carlos Villaverde Amieva (1994), Bajo Pérez (2000), Garulo Muñoz (1983), Granja de la (1998).

${ }^{20}$ Owens (red.) (2000).

${ }^{21}$ Lévy (1995); Viguera Molins, http://revistas.ucm.es/index.php/RFRM/article/viewFile/RFRM02 02110045A/10746

${ }^{22}$ Ruth Vidal-Luengo (2007-IX).

${ }^{23}$ Oliver Asín (1974).
} 
na relacje arabskiego m.in. z latînî oraz ich wpływ na rzeczywistość językową Półwyspu Iberyjskiego. $Z$ artykułów powstałych na ten temat warto też wymienić pracę Juana Chavarría Vargasa ${ }^{24}$, w której autor opisuje 67 toponimów pochodzenia łacińsko-arabskiego.

Poza typowymi badaniami leksykograficznymi (synchronicznymi i diachronicznymi), badaniami skupiającymi się na analizie tekstów źródłowych i ich wybranych elementów (w tym ciekawych obserwacji dotyczących wpływu błędów w grafii na derywaty leksykalne ${ }^{25}$ ) w ostatnich opracowaniach możemy zaobserwować nurt dotyczący analizy interferencji leksykalnych $\mathrm{j}$. arabskiego i hiszpańskiego pod kątem ich wpływu na akwizycję języka hiszpańskiego jako obcego. Jednym z artykułów wpisujących się w ten kierunek badawczy jest praca Eloísy Llavero i Any Ruth Vidal z 2010 roku $^{26}$.

\section{Uwagi metodologiczne i materiał badawczy}

Jak wynika z poprzednich rozdziałów, wiele zapożyczeń z j. arabskiego przechodziło na przestrzeni wieków do kultury i j. hiszpańskiego i funkcjonuje w nim obecnie. Jednak prowadzone badania pokazują też różnice w liczbie wykazywanych przez badaczy arabizmów występujących $\mathrm{w}$ j. hiszpańskim. Wynika to m.in. z przyjętych założeń metodologicznych dotyczących np. pochodzenia arabizmów (teksty pisemne, przekaz ustny) oraz czy w obliczeniach brano pod uwagę wyłącznie poszczególne słowa czy uwzględniano również ich derywaty. Różnice te wynikają też z faktu, że niektóre słowa pojawiają się w źródłach, ale nie funkcjonują w rzeczywistości językowej - dlatego część badaczy ich nie uwzględnia. Innym czynnikiem jest fakt, że pewna grupa zapożyczeń występuje wyłącznie w konkretnych wariantach j. hiszpańskiego, a nie we wszystkich jego standardach. Część zapożyczeń została zapomniana na rzecz zapożyczeń z innych języków, np. z j. angielskiego w wypadku słownictwa z zakresu medycyny.

Biorąc pod uwagę powyższą sytuację, autorki postanowiły sprawdzić status wybranych wyrazów związanych z życiem codziennym. Dobór materiału badawczego nastąpił $\mathrm{z}$ listy wyrazów zamieszczonych w rozdz. 2.2 niniejszego opracowania. Jest to lista najczęściej podawanych słów, które obrazują obecność arabizmów w j. hiszpańskim, i których arabskie pochodzenie potwierdza również słownik DRAE. W związku z powyższym rodzą się pytania: czy te słowa na pewno funkcjonują $\mathrm{w}$ j. hiszpańskim? jak w nim funkcjonują? oraz dlaczego nadal funkcjonują we współczesnej hiszpańszczyźnie? Odpowiedzi na tak postawione pytania wskazują bezpośrednio na zakorzenienie badanych wyrazów w kulturze i j. hiszpańskim.

\footnotetext{
${ }^{24}$ Chavarría Vargas (1997).

${ }^{25}$ Por. Bustamante Costa (2016).

${ }^{26}$ Llavero Ruiz, Vidal Luengo (2010).
} 
Badanie przeprowadzono na 3 płaszczyznach: 1. słowniku DRAE, 2. korpusie j. hiszpańskiego XXI wieku, 3. wymiarach zaproponowanych przez autorki niniejszego opracowania. Te trzy narzędzia badawcze uzupełniają się wzajemnie, ponieważ słownik potwierdza założenia teoretyczne (pochodzenie arabskie), korpus stanowi źródło tekstów w j. hiszpańskim reprezentatywnych dla XXI wieku, a konstrukcja wymiarów pozwala na filtrowanie informacji dostępnych w korpusie i ustalenie funkcjonowania wybranych wyrazów (materiał badawczy) we współczesnej hiszpańszczyźnie.

\subsection{Material badawczy}

Jak już wspomniano materiał badawczy został dobrany w sposób subiektywny, w oparciu o częstość pojawiania się danego wyrazu w materiałach naukowych i opracowaniach dotyczących zapożyczeń z języka arabskiego (najczęściej podawane przykłady zapożyczeń). Drugie kryterium doboru stanowiła kategoria użycia danego wyrazu - słownictwo związane z szeroko rozumianym życiem codziennym użytkowników języka hiszpańskiego.

Ponieważ najczęściej podawane przykłady arabizmów w rozmaitych źródłach różnią się między sobą zarówno zapisem (transliteracją lub transkrypcją), podawanymi znaczeniami, jak i samym pochodzeniem (wariant arabski), dlatego autorki, będąc świadomymi występujących różnic, jako ostateczny wyznacznik przyjęły wskazania słownika Diccionario de la Lengua Española $R A E^{27}$. Stąd w przedstawianym opracowaniu przyjęto za $D R A E$, że materiał badawczy jest pochodzenia arabskiego (słowa bezpośrednio pochodzące z j. arabskiego lub takie, które do arabskiego przeszły z innego języka).

\section{Diccionario de la Lengua Española [RAE]}

Autorki korzystały z 23 edycji słownika w wersji elektronicznej (online) ${ }^{28}$ opublikowanej w październiku 2014 roku. Diccionario de la Lengua Española to obszerne opracowanie akademickie uwzględniające wszystkie warianty i standardy języka hiszpańskiego. Powstał we współpracy z Asociación de Academias de la Lengua Española (ASALE) - stowarzyszeniem zrzeszającym 22 akademie języka hiszpańskiego reprezentujące jego różne geolekty. Wyszukiwanie w wersji online może się odbywać na poziomie różnych parametrów, np. wyszukiwania po wyra-

\footnotetext{
${ }^{27}$ Real Academia Española: Diccionario de la lengua española, 23 edycja [wersja 23.4 online]. $<$ https://dle.rae.es $>$

${ }^{28}$ Należy zauważyć, że słownik ten jest przygotowywany przez Real Academia Española (Hiszpańską Akademię Królewską), która powstała w Madrycie w 1713 z założeniem dbałości o spuściznę kulturową, w tym językową i językoznawczą. Pierwszy słownik powstał w 1. 1726-1739 (Diccionario de autoridades, 6 tomów) i stanowił pierwowzór późniejszej leksykografii akademickiej w Hiszpanii.
} 
zach, wyrażeniach i zwrotach, lematach (z podziałem na dalsze kategorie). Każdorazowo słownik podaje skróconą etymologię wyrazu, dane gramatyczne, znaczenie z podstawowymi konotacjami. $Z$ racji charakteru wersji elektronicznej nie występują w niej przykłady użycia w zdaniach. W odniesieniu do danych zebranych na potrzeby niniejszego badania należy zaznaczyć, że $D R A E$ podaje pochodzenie wyrazów w różny sposób - część wyrazów została wskazana jako wyrazy pochodzące z arabskiego klasycznego (zatem można wnioskować, że zostały zapożyczone z arabskich form pisemnych), część wyrazów została wskazana jako zapożyczenia z dialektów (co pozwala na wniosek, że zostały zapożyczone $\mathrm{z}$ arabskich form ustnych), jednak część opisów słownikowych nie wskazuje na wariant arabski, podając wyłącznie lakoniczną informację, że wyraz pochodzi z arabskiego. Jednocześnie należy zauważyć, że słownik pokazuje transkrypcję lub transliterację wyrazu arabskiego będącego źródłem zapożyczenia, natomiast nie podaje pisowni arabskiej ani wymowy, co oznacza, że przy braku wskazania wariantu arabskiego, z którego pochodzi dany wyraz, wariant ten nie jest możliwy do ustalenia. Jest to istotne ze względu na fakt, że pochodzenie $\mathrm{z}$ konkretnego wariantu j. arabskiego skutkuje zawężeniem pól znaczeniowych danego zapożyczenia.

Podczas opracowywania materiału badawczego autorki zauważyły różnice występujące między opracowaniami naukowymi a słownikiem w zakresie pochodzenia poszczególnych słów, dlatego na potrzeby niniejszego badania pominięto wyrazy, których Słownik DRAE nie potwierdza jako pochodzących (zapożyczonych) $\mathrm{z} \mathrm{j}$. arabskiego ${ }^{29}$. Wybrane wyrazy to rzeczowniki pospolite, w liczbie pojedynczej, związane z nazewnictwem odnoszącym się do szeroko rozumianego życia codziennego. Istotnym kryterium był również wymóg, aby pierwsze znaczenie arabizmu w j. hiszpańskim pokrywało się ze znaczeniem prymarnym funkcjonującym w j. ogólnoarabskim. Poniżej przedstawiono listę alfabetyczną wybranych do analizy wyrazów:

aceituna [z arab. hiszp. azzaytúna, to $\mathrm{z}$ arab. klas. zaytūnah, a to $\mathrm{z}$ aram. zaytūna a, zdrobninie od zaytā]; alberca [z arab. hiszp. alhazána, i to $\mathrm{z}$ arab. klas. hizānah]; alcohol [z arab. hiszp. kuhúl, to $\mathrm{z}$ arab. klas. kuhl]; alfombra $[1 . \mathrm{z}$ arab. hiszp. alhánbal, to $\mathrm{z}$ arab. klas. hanbal; 2. $\mathrm{z}$ arab. hiszp. alhúmra, to $\mathrm{z}$ arab. klas. humrah]; algodón [ $\mathrm{z}$ arab. hiszp. alquțún, to $\mathrm{z}$ arab. klas. quțn]; almohada [z arab. hiszp. almuhádda, to $\mathrm{z}$ arab. klas. mihhaddah]; azotea [z arab. hiszp. assuțáyha, zdrobnienie od sáțh, to $\mathrm{z}$ arab. klas. sațh]; café [z wł. caffe, to z tur. kahve, a to $\mathrm{z}$ ar. klas. qahwa]; jarabe [z arab. hiszp. šaráb, to $\mathrm{z}$ arab. klas. $\check{s}$ arāb]; naranja [z arab. hiszp. naranğa, to $\mathrm{z}$ arab. nāranğ, to $\mathrm{z}$ pers. nārang,

\footnotetext{
${ }^{29}$ Wyrazy brane pod uwagę w badaniu są zapożyczeniami bezpośrednimi. Wyjątek stanowi słowo café, które jest zapożyczeniem pośrednim (por. rozdz. 1 i 2). Autorki zdecydowały się na uwzględnienie tego słowa w badaniu ponieważ nie zmieniło się ono pod względem morfologicznym przy przejściach do kolejnych języków i stanowi bogata ilustrację zintegrowania zapożyczenia pochodzenia arabskiego w j. hiszpańskim.
} 
a to z sanskr. nāranga]; taza [z arab. hiszp. țássa, to z arab. țassah lub arab. klas. țast, a to z pers. tašt].

\section{Corpus de Español del Siglo XXI [CORPES XXI, RAE]}

Szczegółowe aspekty uzusu poszczególnych wyrazów z materiału badawczego autorki przeanalizowały, posługując się materiałami zawartymi w korpusie CORPES $X X I$. Uzasadnia to wybór wskazanych wyżej źródeł (DRAE i CORPES XXI) jako materiałów i narzędzi badawczych wzajemnie się uzupełniających. Corpus de Español del Siglo XXI [CORPES XXI, RAE] podobnie jak Corpus de Referencia del Español Actual (CREA) jest zbiorem tekstów różnego pochodzenia o różnej tematyce, który ze względu na swą objętość został zgromadzony na nośnikach elektronicznych.

Oba wymienione są korpusami ogólnymi (referencyjnymi), zaprojektowanymi w sposób umożliwiający pozyskanie wyczerpujących informacji dotyczących leksyki w danym okresie historycznym. CORPES XXI zawiera między innymi teksty powieści, sztuk teatralnych, scenariuszy filmowych, wiadomości prasowych, esejów, artykułów, transkrypcje wiadomości radiowych i telewizyjnych, transkrypcje rozmów, wystąpień publicznych etc. CORPES XXI uwzględnia policentryczność języka hiszpańskiego - co oznacza zgromadzenie tekstów różnego typu, z różnych krajów hiszpańskojęzycznych. $\mathrm{Z}$ tego względu teksty znajdujące się w CORPES XXI są oznaczone zgodnie z określonymi parametrami, a kodowanie w specjalnie zaprojektowanym systemie umożliwia dostęp do wyszukiwania danych pod kątem wybranych parametrów.

CORPES XXI to projekt zlecony RAE (Academia Real Española) przez akademie języka hiszpańskiego decyzją podjętą podczas kongresu XIII Congreso de la Asociación de Academias de la Lengua Española w Medellín w marcu 2007 roku. Zgodnie z wytycznymi na COPRES XXI miały składać się teksty pisemne oraz ustne pochodzące z Hiszpanii, Ameryki Łacińskiej, Filipin i Gwinei Równikowej z dystrybucją 25 milionów form na każdy rok przypadający na XXI wiek. Pierwsza wersja CORPES XXI została zaprezentowana podczas kongresu VI Congreso Internacional de la Lengua Española w Panamie, w październiku 2013 roku. Od grudnia 2013 roku CORPES XXI pozwala na pozyskiwanie danych dotyczących pojedynczych wyrazów, zwrotów bądź wyrażeń oraz kategorii lub podkategorii gramatycznych. W pierwszej fazie projektu (ukończonej w grudniu 2014 roku) zebrano teksty przypadające na lata 2001-2012. Od roku 2015 publikowane są kolejne, ulepszone wersje CORPES XXI, od wersji 0.8 (kwiecień 2015) do wersji 0.93 w lutym 2021 roku, która obejmuje ponad 316000 dokumentów składających się na 333 miliony form ortograficznych pochodzących z tekstów pisanych oraz transkrypcji wypowiedzi ustnych. $Z$ czego w sekcji fikcja literacka (powieści, scenariusze filmowe, opowiadania, sztuki teatralne) liczba form przekracza 93 miliony; z tekstów niebędących fikcją literacką oraz $\mathrm{z}$ artykułów prasowych (nauki społeczne, zdrowie, polityka, sztuka, technika) to ok. 238 milionów form. Teksty pochodzące z książek 
tworzą zbiór ok. 166 milionów form, a z publikacji prasowych ok. 158 milionów form. Poza tym 6,5 miliona form pochodzi z blogów, wywiadów (zapis cyfrowy) i miscellaneów ${ }^{30}$. Zebrany materiał jest podzielony na pięcioletnie okresy XXI wieku. Zachowano równowagę pomiędzy tekstami z Hiszpanii i Ameryki Łacińskiej wchodzącymi w skład korpusu, ustalając proporcje $30-70 \%$, co oznacza, że teksty zaklasyfikowane jako hiszpańskie stanowią ok. $30 \%$ zbioru.

CORPES XXI dysponuje różnymi parametrami wyszukiwania, które można w dowolny sposób zestawiać. Główne parametry dotyczą pochodzenia tekstów (kraje hiszpańskojęzyczne) oraz tzw. stref lingwistycznych (m.in. Ameryka, w tym USA), podziału na teksty pisemne i transkrypcje tekstów ustnych. Poza tym parametry odnoszą się do ustawień takich, jak typ tekstu, tematyka, nośnik, parametry gramatyczne, szyk zdania, przedział historyczny (okresy pięcioletnie). W niniejszym opracowaniu autorki korzystały z wersji 0.92 oraz z wersji 0.93 CORPES XXI. Obecnie na stronach $R A E$ jest również dostępna wersja testowa 0.94 CORPES XXI (lipiec 2021), w której pojawiły się już nieliczne przykłady z kolejnego okresu pięcioletniego (2021-2025).

Po wstępnej klasyfikacji słownictwa będącego przedmiotem dalszej analizy autorki skupiły się na sprawdzeniu materiału badawczego pod kątem przyjętych na potrzeby niniejszego opracowania wymiarów: częstotliwości występowania w korpusie, typologii (typu) tekstów, tematyki oraz formy gramatycznej i pola znaczeniowego.

\subsection{Wymiary badawcze}

Sformułowane poniżej wymiary ujmują szereg istotnych założeń teoretycznych i praktycznych dotyczących zapożyczeń z j. arabskiego w j. hiszpańskim, ale ich w żaden sposób nie wyczerpują. Wymiary mają charakter ogólny, a ich rolą jest pomoc $\mathrm{w}$ uporządkowaniu różnorodnych danych językowych i kulturowych obu języków. Każdy wymiar ma pokazywać inny aspekt funkcjonowania słów zapożyczonych z j. arabskiego w rzeczywistości językowej i kulturowej j. hiszpańskiego ${ }^{31}$.

Dalsze etapy badawcze powinny objąć pogłębioną analizę ilościową rejestrowanych w korpusach i występujących w tekstach zapożyczeń przy użyciu zaawansowanych narzędzi statystycznych. Wskaźnik dyspersji, częstość relacyjna, ekstensja stylowa, filiacja odmian różnostylowych j. hiszpańskiego ze względu na zapożyczenia $\mathrm{z}$ j. arabskiego czy choćby wyjściowe testy istotności (np. test chi kwadrat) określają zarys procedur badawczych, które zostaną podjęte w nieodległej przyszłości.

\footnotetext{
${ }^{30}$ Zob. https://www.rae.es/banco-de-datos/corpes-xxi

${ }^{31}$ Por. Bańczerowski, J, Oueslati, J. (2020); Bańczerowski, J., Pogonowski J., Zgółka T. (1982); Oueslati, J. (2015).
} 
Wymiary stworzone przez autorki częściowo pokrywają się z parametrami wyszukiwania dostępnymi w CORPES XXI. Należy je traktować jako wzajemnie uzupełniające się elementy badania, ponieważ tylko w ten sposób można zaobserwować pełne spektrum integracji badanych arabizmów z j. hiszpańskim. Wymiary wykorzystują dwa aspekty: ilościowy i jakościowy i dają możliwość sprawdzenia wskazanego słownictwa dwupłaszczyznowo: ze wskazaniem częstość występowania oraz jakości (parametry gramatyczne i semantyczne) wskazującej na pola semantyczne i sposób wykorzystania, a co za tym idzie integracji danego słownictwa z kulturą i językiem hiszpańskim.

\subsubsection{Wymiar częstości}

Wymiar częstości badanego wyrazu w korpusie wskazuje na jego zasięg i rozpowszechnienie w użyciu. W tej części badania autorki skorzystały z narzędzi oferowanych przez CORPES XXI, dzięki którym można dobrać parametry dotyczące pochodzenia tekstów - jak już zostało wspomniane badanie skupiało się na tekstach z Hiszpanii - oraz pięcioletnich przedziałów czasowych, na które podzielono XXI wiek. Zaznaczając parametr Hiszpania, otrzymujemy frekwencję ogólną (całościową) danego wyrazu w korpusie w tekstach pisemnych i transkrypcjach tekstów ustnych, następne kryterium częstości to podział na teksty pisemne oraz transkrypcje tekstów ustnych. W obu powyższych parametrach uzyskujemy dane dotyczące liczby wystąpień danego wyrazu oraz w ilu tekstach dany wyraz wystąpił. Kolejną podkategorią jest podział na poszczególne lata XXI wieku. Autorzy CORPES XXI podzielili je na cztery przedziały czasowe: 2001-2005, 2006-2010, 2011-2015 i 2016-2020. Te przedziały czasowe podzielono również na: a) dane zbiorcze dotyczące wskazanych lat (łącznie teksty pisemne i transkrypcje tekstów ustnych), b) dane dotyczące testów pisemnych we wskazanych przedziałach czasowych, c) dane dotyczące transkrypcji tekstów ustnych we wskazanych przedziałach czasowych. Obrazuje to poniższa tabela.

\begin{tabular}{|c|c|c|}
\hline \multicolumn{3}{|c|}{ Frekwencja ogólna (teksty pisemne i ustne): X wystąpień w Y tekstach } \\
\hline $\begin{array}{c}\text { Frekwencja ogólna: } \\
\text { teksty pisemne i ustne }\end{array}$ & $\begin{array}{c}\text { Frekwencja: } \\
\text { teksty pisemne }\end{array}$ & $\begin{array}{c}\text { Frekwencja: } \\
\text { teksty ustne }\end{array}$ \\
\hline X wystąpień w Y tekstach & $\begin{array}{c}\text { Ogólna: } \\
\text { X wystąpień w Y tekstach }\end{array}$ & $\begin{array}{c}\text { Ogólna: } \\
\text { X wystąpień w Y tekstach }\end{array}$ \\
\hline 2001-2005 liczba wystąpień X & 2001-2005 liczba wystąpień X & 2001-2005 liczba wystąpień X \\
\hline 2006-2010 liczba wystąpień X & 2006-2010 liczba wystąpień X & 2006-2010 liczba wystąpień X \\
\hline 2011-2015 liczba wystąpień X & 2011-2015 liczba wystąpień X & 2011-2015 liczba wystąpień X \\
\hline $2016-2020$ liczba wystąpień X & $2016-2020$ liczba wystąpień X & 2016-2020 liczba wystąpień X \\
\hline
\end{tabular}


Należy jednak pamiętać, że pomimo przedstawienia statystyki danego wyrazu przy analizie tego wymiaru konieczne jest uwzględnienie faktu, że wymiar częstości nie jest jednakowy dla każdego badanego wyrazu, np. wyraz alcohol i wyraz jarabe - oba związane z „kuchnią” - mają znacząco różną częstość. Jednak dopiero w wymiarze tematyka widzimy istotę danego wyrazu, jego zakres oraz zakorzenienie w kulturze hiszpańskiej (pomimo niskiej statystyki). Na podstawie opisanych wyżej parametrów korpusowych autorki stworzyły wymiar częstości, wybierając w wyszukiwarce korpusowej parametry takie, jak: obszar geograficzny - Hiszpania, i pięcioletnie okresy, na które podzielono XXI w. Pozostałe parametry w tym wymiarze były zastosowane jako ,wszystkie dziedziny”. W ten sposób otrzymano szczegółowe wskazania, jak na przestrzeni ww. pięcioletnich okresów kształtowało się użycie wybranego słownictwa na terenie Hiszpanii.

\subsubsection{Wymiar typ tekstu}

Wymiar dotyczący typu tekstu, w którym pojawia się dane słowo, wskazuje zakorzenienie danego wyrazu w języku i kulturze hiszpańskiej. Jest to wymiar, co do którego CORPS XXI proponuje różne parametry - zarówno odnoszące się do tekstów literackich (fikcja), jak i współczesnych mediów. Zasoby korpusu hiszpańszczyzny XXI wieku zostały podzielone na główne typy, takie jak teksty literackie (fikcja), wiadomości, blogi, teksty akademickie, wywiady, opinie, teksty popularyzatorskie oraz szereg innych. Kategoria ta w większości powtarza te same typy tekstów, jednak przy niektórych wyrazach autorki zauważyły drobne różnice we wskazywanych parametrach (np. przy wyrazie alfombra pojawiają się też parametry takie, jak „,dyskurs”, „,folder”, czy „biografia i wspomnienia”; przy wyrazie azotea pojawia się parametr „krytyka”, powracający przy wyrazie café, przy wyrazie algodón parametr „reportaż”).

$\mathrm{W}$ parametrach związanych z typem tekstu, podobnie jak w parametrach związanych z częstością istnieje możliwość sprawdzenia danych ogólnych (teksty pisemne i transkrypcje tekstów ustnych) dotyczących całości zebranych materiałów przypisanych do danego typu tekstu, jak również rozbicie badania na teksty pisemne i transkrypcje tekstów ustnych i uzyskanie szczegółowych danych w tych parametrach wyszukiwania. W wymiarze dotyczącym typu tekstu autorki wybrały parametr „wszystkie”, równocześnie zaznaczając obszar Hiszpanii i sprawdziły je pod kątem występowania w tekstach pisemnych oraz transkrypcjach tekstów ustnych uzyskując szczegółowe dane dotyczące terenów Hiszpanii.

\subsubsection{Wymiar tematyka}

Wymiar dotyczący tematyki tekstów zebranych w CORPES XXI wskazuje, podobnie jak wymiar odnoszący się do typu tekstu, na zakorzenienie badanego wyrazu w języku i kulturze. Wskazuje też pola semantyczne, w których użytkownicy języka 
hiszpańskiego najczęściej wykorzystują badane arabizmy oraz ich zakres dziedzinowy, sposób wykorzystania i uzus. W korpusie parametry związane $\mathrm{z}$ tematyką zostały podzielone na ok. 10 tematów, które związane są m.in. z aktualnościami / czasem wolnym / życiem codziennym; sztuką / kulturą / spektaklami; teatrem; naukami ścisłymi i technologią; polityką / ekonomią i sądownictwem; zdrowiem; naukami społecznymi / wierzeniami / ideami. W parametrach tych pojawiły się też jako tematyka scenariusze oraz opowiadania. Podobnie jak w poprzednich dwóch wymiarach, w wymiarze związanym z tematyką CORPES XXI umożliwia przeprowadzenie badania ogólnego wszystkich zebranych tekstów, jak również podział na badania szczegółowe i zebranie osobnych danych dotyczących tekstów pisemnych i transkrypcji tekstów ustnych.

Za wymiar tematyka autorki przyjęły wyszukiwanie dotyczące obszaru Hiszpanii i wszystkich parametrów dotyczących tematyki oferowanych przez korpus (teksty pisemne i transkrypcje tekstów ustnych), uzyskując szczegółowe dane dotyczące częstości poszczególnych wyrazów w zaznaczonych parametrach oraz dostęp do tekstów z zaznaczonego zakresu tematycznego.

\subsubsection{Wymiar forma gramatyczna}

Forma gramatyczna jest jednym z wymiarów wskazujących na sposób integracji i zasięg danego wyrazu w strukturach języka hiszpańskiego. W wypadku tego wymiaru korpus CORPES XXI dysponuje parametrami takimi, jak rodzaj i liczba oraz części mowy, wg których można ustawić parametry wyszukiwania. Można też za pomocą bardziej zaawansowanego wyszukiwania sprawdzić szyk zdania i „łączliwość" danego wyrazu. Forma gramatyczna w języku docelowym wskazuje na sposób integrowania oraz modyfikacje, jakie miały miejsce w stosunku do arabskiego pierwowzoru. Wymiar gramatyczny przyjęty przez autorki opracowania opierał się na sprawdzeniu jak badane wyrazy (rzeczowniki) zachowują się w j. hiszpańskim ze względu na rodzaj i liczbę, ze względu na bezpośrednie otoczenie przed i po (uwzględniono kategorię rzeczownika, czasownika, przymiotnika i przyimka). Przykłady ilustrujące otoczenie zostały wybrane ze wszystkich typów tekstów w wyszukiwaniu zaawansowanym (,fikcja” / „nie fikcja”).

\subsubsection{Wymiar pole semantyczne}

Ostatni, piąty wymiar wskazuje mechanizmy pomagające $\mathrm{w}$ zakorzenieniu się oraz integracji zapożyczeń z języka arabskiego w języku i kulturze hiszpańskiej. Ukazuje modyfikacje znaczeniowe, jakim uległy poszczególne wyrazy w stosunku do pierwowzoru arabskiego i uzus stosowany przez rodzimych użytkowników języka hiszpańskiego. Wymiar dotyczący pola semantycznego nie występuje jako para- 
metr w korpusie - powstał w oparciu o poprzednie wymiary i dotyczył analizy poszczególnych wyrazów występujących w tekstach wyszukanych pod kątem tematyki (wymiar 4.2.3), typu tekstu (wymiar 4.2.2) oraz różnych konotacji przez nie wskazanych.

\section{Zasięg arabskich zapożyczeń leksykalnych w języku hiszpańskim}

\subsection{Częstość}

Frekwencję ogólną poszczególnych słów w tekstach pisemnych i transkrypcjach tekstów ustnych podzielono zgodnie z przyjętym wzorem na: frekwencję wysoką (powyżej 5000 wystąpień), średnią (pomiędzy 1000 a 5000 wystąpień) i niską (poniżej 1000 wystąpień). Dla poszczególnych słów wynik kształtuje się następująco: pierwsza grupa (wysoka) to słowa café (10041 wystąpień w 2365 tekstach), alcohol (7110 wystąpień w 1866 tekstach), druga grupa (średnia) obejmuje następujące słowa: alfombra (1474 wystąpień w 673 tekstach), algodón (1320 wystąpień w 575 tekstach), almohada (1046 wystąpień w 453 tekstach), naranja (2767 wystąpień w 1130 tekstach), taza (1773 wystąpień w 632 tekstach), a trzecia grupa (niska) to słowa: aceituna (351 wystąpień w 159 tekstach), alberca (97 wystąpień w 52 tekstach), azotea (552 wystąpień w 229 tekstach), jarabe (279 wystąpień w 127 tekstach), wykazują niską frekwencję w CORPES XXI.

Kolejny obszar badawczy odnoszący się do frekwencji dotyczył frekwencji danych słów w tekstach pisemnych w opozycji do tekstów ustnych:

Jak można zaobserwować na przykładach podanych w tabeli nr 1 i tabeli nr 2 frekwencja poszczególnych słów w tekstach pisemnych jest znacząco wyższa niż frekwencja tych samych słów w transkrypcjach tekstów ustnych. W tekstach pisemnych poszczególne słowa wykazywały następujące frekwencje: aceituna (336 wystąpień w 154 tekstach), alberca (97 wystąpień w 52 tekstach), alcohol (6994 wystąpienia w 1831 tekstach), alfombra (1471 wystąpień w 670 tekstach), algodón (1204 wystąpienia w 519 tekstach), almohada (1041 wystąpień w 451 tekstach), azotea (552 wystąpienia w 229 tekstach), café (9886 wystąpień w 2307 tekstach), jarabe (274 wystąpienia w 125 tekstach), naranja (2739 wystąpień w 1114 tekstach), taza (1765 wystąpień w 628 tekstach). W tekstach ustnych frekwencja była bardzo niska, w wypadku niektórych słów korpus nie wykazywał transkrypcji tekstów ustnych (alberca (0), azotea (0)), frekwencja pozostałych wyrazów kształtowała się następująco: aceituna (15 wystąpień w 5 tekstach), alcohol (116 wystąpień w 35 tekstach), alfombra (3 wystąpienia w 3 tekstach), algodón (10 wystąpień w 5 tekstach), almohada (5 wystąpień w 2 tekstach), café (155 wystąpień w 58 tekstach), jarabe (5 wystąpień w 2 tekstach), naranja (28 wystąpień w 16 tekstach), taza (8 wystąpień w 4 tekstach). 
Tabela nr 1. Frekwencja: teksty pisemne

\begin{tabular}{|c|c|c|c|c|c|c|c|c|c|c|c|}
\hline \multirow[b]{2}{*}{ LATA } & \multicolumn{11}{|c|}{ BADANE SLOWA } \\
\hline & aceituna & alberca & alcohol & alfombra & algodón & almohada & azotea & café & jarabe & naranja & taza \\
\hline 2001-2005 & 84 & 18 & 1610 & 290 & 345 & 286 & 186 & 2579 & 56 & 701 & 550 \\
\hline $2006-2010$ & 74 & 30 & 3260 & 588 & 332 & 246 & 146 & 2677 & 98 & 739 & 479 \\
\hline 2011-2015 & 121 & 29 & 1383 & 317 & 324 & 259 & 161 & 2668 & 61 & 696 & 419 \\
\hline $2016-2020$ & 57 & 20 & 741 & 279 & 203 & 250 & 59 & 1962 & 59 & 603 & 317 \\
\hline
\end{tabular}

Tabela nr 2. Frekwencja: transkrypcje tekstów ustnych

\begin{tabular}{|c|c|c|c|c|c|c|c|c|c|c|c|}
\hline & \multicolumn{11}{|c|}{ BADANE SLOWA } \\
\hline LATA & aceituna & alberca & alcohol & alfombra & algodón & almohada & azotea & café & jarabe & naranja & taza \\
\hline 2001-2006 & 13 & - & 25 & 1 & 3 & 1 & - & 16 & - & 12 & 1 \\
\hline 2005-2010 & - & - & 62 & - & 1 & 4 & - & 117 & 4 & 3 & 6 \\
\hline 2011-2015 & 2 & - & 23 & - & 6 & - & - & 18 & 1 & 11 & 1 \\
\hline 2016-2020 & - & - & 6 & 2 & - & - & - & 4 & - & 2 & - \\
\hline
\end{tabular}

Tabela nr 1 i tabela nr 2 pokazują również, jak zmieniała się frekwencja poszczególnych słów występujących w tekstach pisemnych i transkrypcjach tekstów ustnych w kolejnych okresach pięcioletnich XXI wieku. Ogólnie można przyjąć, że najniższą frekwencję $\mathrm{w}$ tekstach pisemnych poszczególne słowa wykazywały w latach 2001-2005 oraz 2016-2020 - czyli w początkowych i końcowych latach, które obejmuje korpus. W odniesieniu do transkrypcji tekstów ustnych rozkład frekwencji badanych słów jest nierównomierny, można natomiast jednoznacznie wskazać na ostatni okres pięcioletni (2016-2020) jako ten, w którym dla większości słów (aceituna, alberca, algodón, almohada, azotea, jarabe, taza) nie wykazano transkrypcji tekstów ustnych. Powyższe dane podsumowują następujące wykresy:

\section{Frekwencja: teksty pisemne}

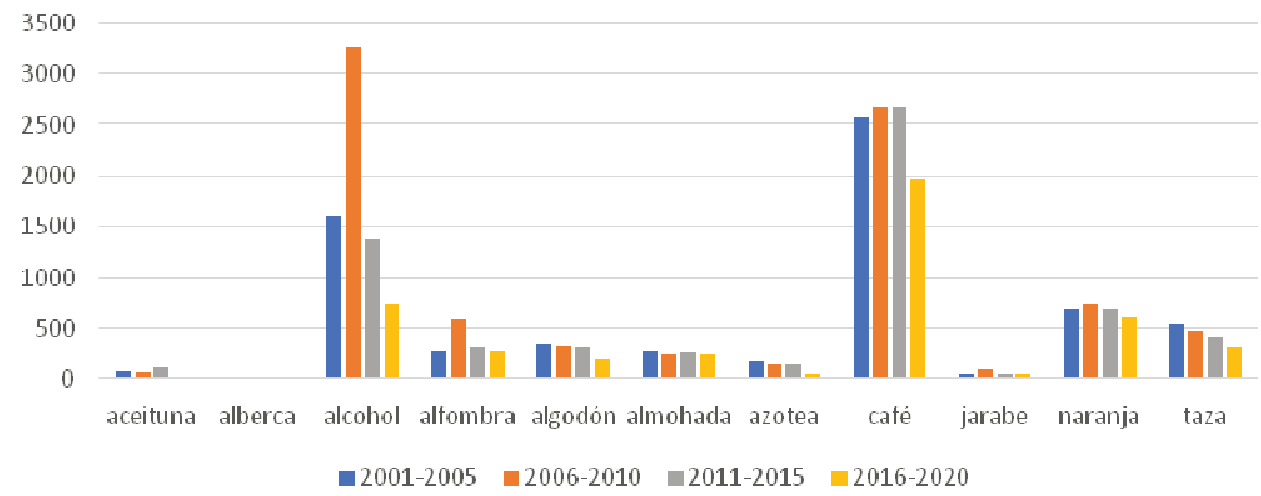




\section{Frekwencja: transkrypcje tekstów ustnych}

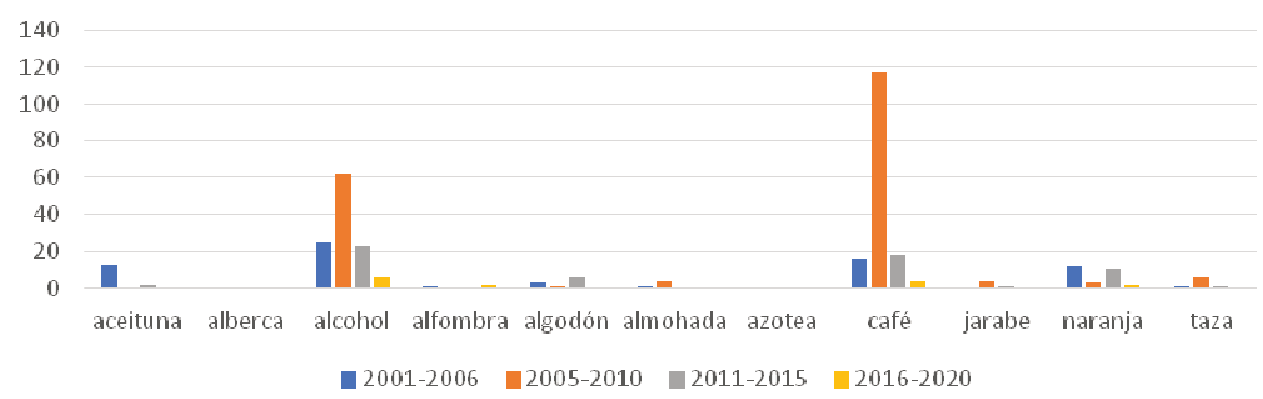

\subsection{Typ tekstu}

Celem tej części badania jest pokazanie, w jakiego typu tekstach występują badane słowa, które typy tekstów są dominujące i jaka jest frekwencja poszczególnych słów w danym typie tekstu. Za względu na znikomą liczbę danych dotyczących transkrypcji tekstów ustnych w kategorii „typ tekstu” autorki uwzględniły w wynikach badań wyłącznie teksty pisemne.

Wszystkie badane słowa zostały sklasyfikowane w korpusie wg następujących typów tekstów: „teksty popularyzatorskie”, „fikcja”, „widomości”, „blog”, „teksty akademickie”, „wywiad”, „inne”. W wypadku wyszukiwania słów algodón, alfombra, azotea, café występują też inne typy tekstów, takie jak: „, folder”, „,iografia”, „reportaż”, „przemówienie”, „krytyka”. Typologia nie jest zatem jednakowa dla każdego słowa.

Ze względu na frekwencję badanych słów przypisanych do danych typów tekstów dominują kategorie takie, jak: „fikcja” (max. frekwencja to 6502, min. to 50), „teksty popularyzatorskie” (max. frekwencja to 689, min. to 12), wiadomości (max. frekwencja to 232 , min. to 3 ) i blog (max. frekwencja to 400 , min. to 1 ).

Ze względu na frekwencję danego słowa w poszczególnych typach tekstów wyniki badania kształtują się następująco: słowa takie, jak alberca (50), alcohol (1657), alfombra (935), algodón (456), almohada (818), azotea (426), café (6502), taza (1289), naranja (822), najczęściej występują w kategorii „fikcja”, natomiast słowa jarabe (114) i aceituna (120) najczęściej spotykane są w typie „teksty popularyzatorskie”.

\subsection{Tematyka}

Poniżej zostały zaprezentowane tematy, w których pojawiły się badane słowa. Autorki porównały frekwencję danych słów w parametrach tematycznych, aby uzyskać dane dotyczące tematyki dominującej w badanych słowach w tekstach pisemnych i transkrypcjach tekstów ustnych.

Wszystkie badane słowa zostały sklasyfikowane w korpusie w następujących tematach: „aktualności, czas wolny, życie codzienne”, „powieść”, „sztuka, kultura”, 
„,nauki ścisłe i technologia”, „polityka, ekonomia, sądownictwo”, „zdrowie”, „,nauki społeczne, wierzenia”, „teatr”, „opowiadanie”, „scenariusz”. W korpusie przy badanych słowach w kategoriach tematycznych dotyczących transkrypcji tekstów ustnych występuje wpis „,brak danych”.

Ze względu na frekwencję badanych słów w danej tematyce dominują kategorie takie, jak „powieść” (max. frekwencja to 5164, min. to 39), ,aktualności, czas wolny, życie codzienne" (max. frekwencja to 1417, min. to 37), „sztuka, kultura” (max. frekwencja to 436, min. to 16). Kategorie z najmniejszą frekwencją to „scenariusz” (max. frekwencja to 228 , min. to 2), ,polityka i ekonomia” (max. frekwencja to 385 , min. to 1), ,nauki ścisłe” (max. frekwencja to 252, min. to 14).

Ze względu na frekwencję danego słowa w poszczególnych kategoriach wyniki badania kształtują się następująco: słowa takie, jak naranja (977), aceituna (69), algodón (393), najczęściej występują w kategorii „aktualności, czas wolny, życie codzienne", słowa takie, jak café (5164), alfombra (756), almohada (630), azotea (254), taza (986), alberca (44) najczęściej występują w kategorii „powieść”, słowa takie, jak alcohol (3092), jarabe (98) najczęściej występują w kategorii „zdrowie”. Należy zwrócić uwagę, że dysproporcje frekwencyjne wynikają z samej budowy korpusu liczby danych słów występujących w samym korpusie, co przekłada się na ich frekwencję w poszczególnych kategoriach. Kolejnym istotnym czynnikiem jest fakt, że w badaniu brano pod uwagę wyszukiwanie rzeczowników w 1. poj., co również wpływa na wynik wyszukiwania. Podane w nawiasach liczby odpowiadają częstości danego słowa w każdej kategorii.

\subsection{Gramatyka}

Część badań dotyczących gramatyki ma na celu pokazać, jak zachowują się zapożyczenia arabskie w systemie gramatycznym j. hiszpańskiego, inaczej mówiąc czy słowa pochodzenia arabskiego dostosowały się do zasad gramatycznych j. hiszpańskiego i zachowują się jak słowa pochodzenia łacińskiego, czy wykazują opór i nie integrują się gramatycznie z językiem docelowym - hiszpańskim. W niniejszej części autorki nie pretendują do zbadania całości zagadnień gramatycznych dotyczących zapożyczeń arabskich $\mathrm{w}$ j. hiszpańskim, przedstawią tylko niektóre ich aspekty w następujących obszarach:

\subsubsection{Rodzaj i liczba rzeczownika}

Słowa, które w j. arabskim są r.m. i w j hiszpańskim są r.m.

algodón (...) el lino, el algodón, el yute, etc. se emplean como fibras textiles. - „(..) len, bawełna i juta etc. są używane jako włókna tekstylne"; 
jarabe (...) al revolver en el cajón de la cómoda en busca de su jarabe para la tos $(\ldots)-,(\ldots)$ szperając w szufladzie w poszukiwaniu syropu na kaszel (...)”;

alcohol No me apetece mucho beber alcohol. - „Naprawdę nie mam ochoty na picie alkoholu".

W wyrazach algodón i alcohol zapożyczenia zostały utworzone zgodnie z gramatyką arabską (r.m. kończy się na spółgłoskę). W przypadku słowa jarabe zmodyfikowano wzór gramatyki arabskiej poprzez dodanie samogłoski ,e”.

Słowa, które w j. arabskim są r.m., a w j. hiszpańskim są r.ż.

alfombra En el suelo, una vieja alfombra. - „Na podłodze stary dywan”;

azotea Alguien ha disparado desde la azotea de la casa de enfrente - „Ktoś wystrzelił z tarasu na dachu domu naprzeciwko".

W tych wyrazach widoczne są duże zmiany fonetyczne i morfologiczne, końcówka -a oznacza w j. hiszpańskim r.ż.

Słowa, które w j. arabskim są r.ż. i w j. hiszpańskim też są r.ż.

aceituna Un vermut de domingo, con su aceituna rellena de anchoa $(, \ldots)$ - „Niedzielny wermut z oliwką nadziewaną anchois, (...)";

alberca Se conformó con bañarse en la alberca - „Zadowolił się kąpielą w basenie”;

almohada (...) su cara muy pálida en la almohada y sus ojos siguiéndola por la habitación - „(...) jej bardzo blada twarz na poduszce i jej oczy śledzące ją po pokoju";

naranja ¿Te pelo una naranja? - „Obrać ci pomarańczę?”;

taza (...) me uni a mi padre que me estaba preparando una taza de café con leche.,- ,...) dołączyłem do ojca, który przygotowywał mi filiżankę kawy z mlekiem".

Zarówno w j. arabskim, jak i j. hiszpańskim końcówka -a oznacza rodzaj żeński rzeczownika.

Słowa, które w j. arabskim są r.ż. a w j. hiszpańskim są r.m.

café Vamos, Segundo, el café está listo. - „Dalej, Segundo, kawa jest gotowa”.

Słowo to w j. arabskim funkcjonuje w r.ż. qahwa, końcówka w wersji przekazu ustnego ,-a" pojawiająca się w wymowie oznacza rodzaj żeński. Oznacza to, że w słowniku j. hiszpańskiego uwzględniono wersję ustną, a nie wersję pisemną, co pozwala przypuszczać, że zapożyczenie przeszło do j. hiszpańskiego zgodnie z wymową, a nie ortografią standardu arabskiego.

Wybrane do analizy słowa (rzeczowniki, 1. poj., r.m. / r.ż., w j. hiszpańskim) w j. hiszpańskim przyjęły formy 1. mn. r.m. / r.ż. na podstawie zasad gramatycznych j. hiszpańskiego - poprzez dodanie końcówek ,,-s” (rzeczowniki zakończone na samogłoskę) oraz ,-es” (rzeczowniki zakończone na spółgłoskę). 


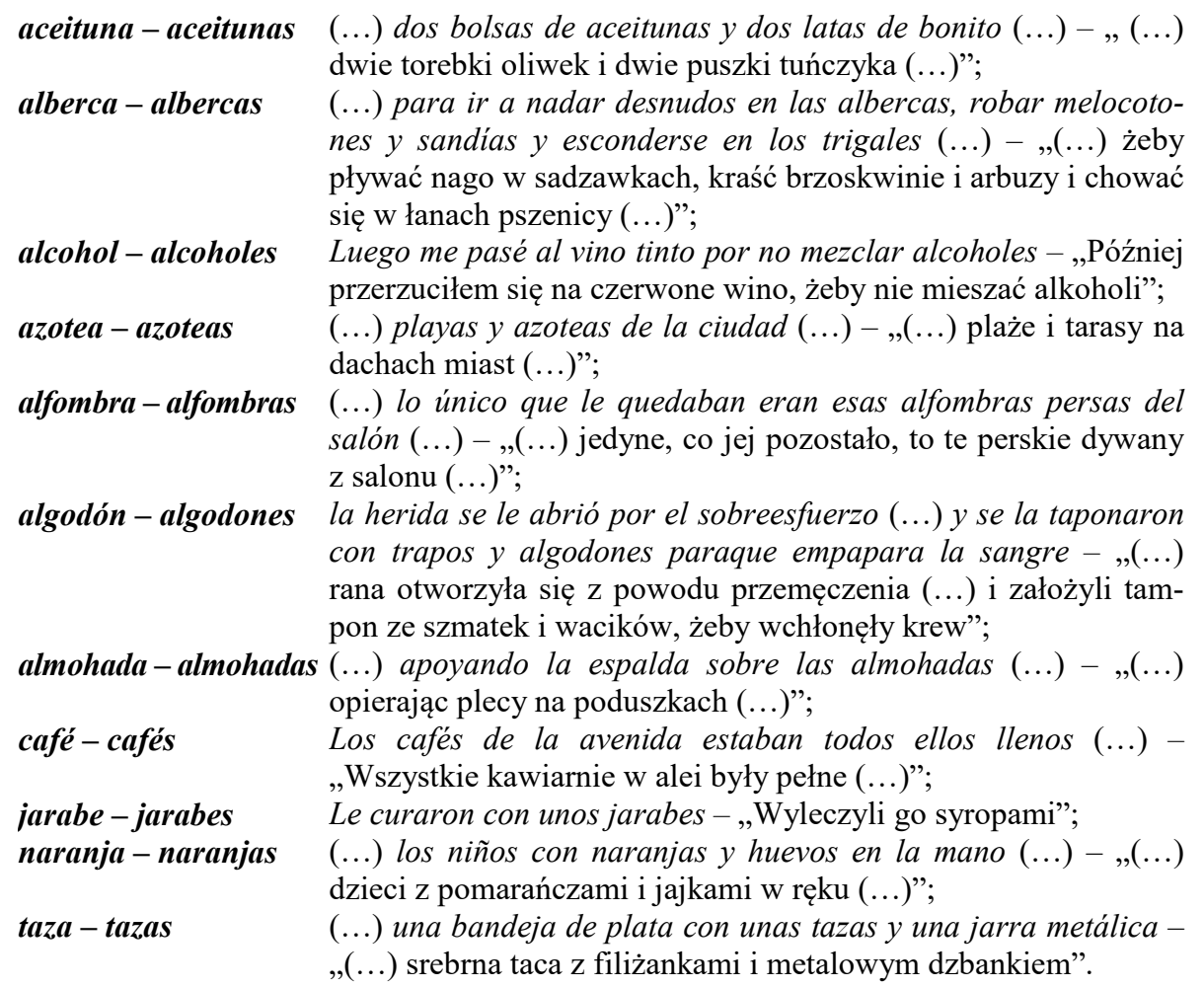

\subsubsection{Kookurencja}

W tej części badania wybrano wyłącznie otoczenie bezpośrednie ${ }^{32}$ (przed i po) w czterech kategoriach gramatycznych: rzeczowniki, czasowniki, przymiotniki i przyimki. Podane przykłady dotyczą tekstów z parametru wyszukiwania: ,,wszystkie”. Z powodu ograniczeń objętościowych niniejszego opracowania w poniższej egzemplifikacji zdecydowano się wymienić słowa spełniające daną kategorię, ograniczając się do przedstawienia pojedynczych przykładów.

\subsubsection{Kookurencja przed badanym slowem}

Bezpośrednie połączenia badanych słów z rzeczownikami w szyku „rzeczownik + badane słowo" występują najczęściej przy nazwach własnych i określeniach dotyczących kolorów. Słowa, które bezpośrednio łączą się z rzeczownikami, to, np.:

\footnotetext{
${ }^{32}$ Wychodząc z założenia, że rzeczownik wraz z rodzajnikiem (określonym / nieokreślonym) jest liczony jako jeden wyraz.
} 
naranja Agente Naranja- „Pomarańczowy Agent”,

aceituna brillo aceituna en los ojos grandes - „oliwkowy blask w dużych oczach”.

Połączenia z czasownikami, w których czasownik występuje przed badanym słowem, są częste. Należy jednak pamiętać, że zgodnie z zasadami gramatyki hiszpańskiej przed rzeczownikiem stawiamy rodzajniki (określone / nieokreślone), a ponieważ wybrane do badania słowa to rzeczowniki w 1. poj. w większości wypadków między czasownikiem a badanym słowem występuje rodzajnik. Poniżej kilka wybranych przykładów:

café Nadie hace el café como Antonio - „Nikt nie robi takiej kawy jak Antonio”, José (...) tráeme un café con leche - „José (...) przynieś mi kawę z mlekiem";

aceituna Es época de recoger la aceituna - „to okres zbioru oliwek”;

alfombra (...) dispuestos a recorrer la alfombra - „gotowi chodzić po dywanie";

algodón sacó el algodón - „wyciągnął bawełnę”,

(...) como si fuera algodón - ,jakby to była bawełna", ya no queda algodón como éste - „nie ma już takiej bawełny”.

W wypadku połączeń z przymiotnikami (schemat: przymiotnik + badane słowo) należy stwierdzić, że wszystkie badane słowa mogą występować w takich połączeniach. Poniżej przytoczono wybrane przykłady:

aceituna la mejor aceituna de España - „najlepsza oliwka w Hiszpanii”;

taza (...) a modo de improvisada taza de retrete (...) - ,(...) jako prowizoryczna muszla klozetowa (...)";

alfombra (...) una vieja alfombra $(\ldots)-,(\ldots)$ stary dywan $(\ldots) ”$.

Wszystkie badane słowa łączą się z przyimkami. Najczęściej spotykane połączenie występuje z przyimkiem de (od, z, o) wskazującym m.in. na. przynależność, pochodzenie, materiał, cechy lub właściwości, cel. Inne często spotykane w tych połączeniach przyimki to por (przez - wskazuje miejsce lub sposób; w - wskazuje miejsce), en (w - wskazuje miejsce), con (z - wskazuje towarzystwo, relację, sposób, zachowanie). Poniżej przytoczono wybrane przykłady:

aceituna (...) cada tipo de aceituna - „(...) każdy rodzaj oliwki”;

taza A un lado, dos urinarios $y$, frente a ellos, dos cabinas con taza - „Z jednej strony dwa pisuary, a przed nimi dwie kabiny z toaletami”;

alfombra Las revistas por la alfombra (...) - „Czasopisma na dywanie (...)”;

algodón (...) un traje de algodón color crema (...) - „(..) kremowy, bawełniany garnitur (...)";

café $\quad(.$.$) en el café Metropol (. .)-.,(\ldots)$ w kawiarni Metropol (...)”.

33 „Pomarańczowy Agent” (czynnik pomarańczowy) - to nazwa funkcjonująca na określenie trującej substancji na bazie herbicydów wykorzystywanej przez wojska USA podczas wojny w Wietnamie. 


\subsubsection{Kookurencja za badanym słowem}

Bezpośrednie połączenia badanych słów z rzeczownikami w szyku „badane słowo + rzeczownik" występują w następujących przykładach:

alfombra (...) alrededor de una alfombra el espacio fue evolucionando $(\ldots)-,(\ldots)$ wokół dywanu przestrzeń ewoluowała (...)";

algodón (...) un traje de algodón color crema $(\ldots)-,(\ldots)$ kremowy, bawełniany garnitur (...)".

Połączenia z czasownikami, w których czasownik występuje po badanym słowie, są częste. Obrazują je przykłady takie, jak:

café Vamos, Segundo, el café está listo. - „Dalej, Segundo, kawa jest gotowa”;

aceituna (...) médicos y enfermeros, que prestaron asistencia al niño que murió al atragantarse con una aceituna realizaron $(. .)-.,(. .$.$) lekarze i pielęgnia-$ rze, którzy udzielili pomocy dziecku zmarłemu z powodu zadławienia się oliwką zrealizowali (...)";

alfombra La alfombra queda vacía. - „Dywan pozostaje pusty”;

algodón (...) el algodón sustituyó a las fibras de (...) - „(..) bawełna zastąpiła włókna z (...)".

W wypadku połączeń z przymiotnikami (schemat: badane słowo + przymiotnik) należy stwierdzić, że wszystkie badane słowa mogą występować w takich połączeniach. Poniżej kilka przykładów:

aceituna la aceituna molida - „Zmielona oliwka”;

alfombra alfombra voladora - „latający dywan”;

algodón vestido de algodón azul turquesa - „turkusowa bawełniana sukienka”;

taza también hay una taza rota y una cucharilla - ,jest też potłuczona filiżanka i łyżeczka".

Wszystkie badane słowa łączą się z przyimkami. Najczęściej spotykane połączenie występuje z przyimkiem de (od, z, o) wskazującym m.in. na. przynależność, pochodzenie, materiał, cechy lub właściwości, cel. Inne często spotykane w tych połączeniach przyimki to en ( $\mathrm{w}$ - wskazuje miejsce), con ( $\mathrm{z}$ - wskazuje towarzystwo, relację, sposób, zachowanie) czy $a$ (do, przy, na, za, o wskazuje m.in. na kierunek, odległość). Poniżej przytoczono wybrane przykłady:

aceituna la aceituna en esa zona - „oliwka w tej okolicy”;

taza taza de café - filiżanka kawy,

llevándose la taza a los labios - ,podnosząc filiżankę do ust”;

café un café con leche - „kawa z mlekiem”;

alfombra una alfombra con sillas alrededor - „dywan z krzesłami dookoła”;

algodón camisetas de algodón con mangas - „bawełniane koszulki z rękawami”. 


\subsection{Pola semantyczne}

Słowa, których prymarne znaczenie w j. hiszpańskim jest zgodne z prymarnym znaczeniem $\mathrm{w} \mathrm{j}$. arabskim
alcohol
No me apetece mucho beber alcohol - „Naprawdę nie ma ochoty na picie alkoholu";
alfombra (...) una larga alfombra roja y un pequeño grupo de fotógrafos $(\ldots)-,(\ldots)$ długi, czerwony dywan i mała grupa fotografów (...)";
algodón Lacamisa azul claro de algodón hecha a medida. - „Jasnoniebieska baweł- niana koszula szyta na miarę";
almohada Ella escondióla cabeza bajo la almohada (...) - „Ukryła głowę pod po- duszką";
naranja ¿Te pelo una naranja? - „Obrać ci pomarańczę?”,
(...) y pedía de postre una naranja - „,...) a na deser prosił pomarańczę”;
café Vamos a tomar un café, que lo necesitas - „Napijmy się kawy, potrzebujesz tego".

Słowo café jest rozumiane jako wszystkie znaczenia = kawa (roślina), ziarno kawy i napój, funkcjonuje też w znaczeniu „kawiarnia”; to znaczenie występuje również w j. arabskim. W obu językach występuje drugie określenie al-maqhā dominujące $\mathrm{w}$ standardzie j. arabskiego, a w dialektach nadal funkcjonuje al-qahwa, co oznacza, że to zapożyczenie $\mathrm{w}$ j. hiszpańskim funkcjonuje zarówno $\mathrm{w}$ znaczeniu arabskiego standardowego, jak i dialektu. W j. hiszpańskim drugim określeniem odnoszącym się do miejsca jest cafetería.

Słowa, których prymarne znaczenie w j. hiszpańskim jest zgodne częściowo z prymarnym znaczeniem $\mathrm{w} j$. arabskim

azotea 'odas las noches subía a la azotea y exploraba el firmamento - „Każdej ocy wchodził na taras na dachu i badał niebo";

w j. arabskim rdzeniowe znaczenie słowa sațah oznacza wszystko to, co jest płaskie (np. taras, dach, statek), od tego pochodzi nazwa sațah jako część domu - dach.

jarabe Zulema me ha puesto dos crepes con jarabe de arce (...) - „Zulema dala mi dwa naleśniki z syropem klonowym (...)”;

w j. arabskim rdzeniowe znaczenie słowa šarāb oznacza wszystko, co jest pitne (do picia) ale uzus wskazuje na dominację znaczenia wino (alkohol), a w niektórych dialektach j. arabskiego oznacza alkohol wszelkiego rodzaju, w obszarze medycyny jest stosowany w znaczeniu syrop (np. na kaszel).

alberca Creo recordar que hay huertas y una alberca, al lado de ese monasterio (...) -,,Pamiętam, że obok klasztoru są sady i sadzwka (...)”. 
W j. arabskim al-birka oznacza naturalny zbiornik wodny (sadzawka / bajoro), natomiast $\mathrm{w} \mathrm{j}$. hiszpańskim prymarne znaczenie pozostało (zbiornik wodny), ale oznacza zazwyczaj sztucznie stworzony zbiornik.

Słowa, których prymarne znaczenie w j. hiszpańskim nie jest zgodne z prymarnym znaczeniem $w \mathrm{j}$. arabskim

aceituna ¡Mamá, Nicolás ha cogido una aceituna de la mesa! - „Mamo, Nicolas zabrał oliwkę ze stołu!";

$\mathrm{w} \mathrm{j}$. arabskim prymarne znaczenie az-zaytūna, to drzewo oliwne, a owoc - oliwka to habbat zaytūn, w niektórych dialektach i kontekstach możemy spotkać się z użyciem az-zaytūna na określenie oliwki (owoc), które jest zgodne ze znaczeniem uwzględnianym przez słowniki j. arabskiego.

taza Toma una taza de té. - „Bierze filiżankę herbaty”.

W j. arabskim oznacza okrągłe, głębokie naczynie, które może służyć do gotowania lub do picia z niego. W niektórych zastosowaniach dialektalnych taza oznacza wyłącznie metalowe puszki, które wykorzystywano do innych celów (jako kubki, garnki etc.).

Słowa pozostajace $\mathrm{w}$ tej samej formie gramatycznej (rzeczowniki, 1. poj.), które uzyskały nowe znaczenie w j. hiszpańskim i funkcjonuja jako rzeczowniki

aceituna (...) antes de que terminara la temporada de la recogida de aceituna, por fin se escaparian juntos. - „(...) zanim sezon zbioru oliwek dobiegnie końca, uciekną razem";

zgodnie ze znaczeniami słowa aceituna podanymi w $D R A E$ wyraz ten oznacza również „w kalendarzu rolniczym czas zbioru oliwek”; znaczenie to nie wystąpiło w korpusie.

taza Alfredo abrió y cerró la puerta del baño, encendió un cigarro, se sentó en la taza sin levantar la tapa, miró el reloj, las once menos cuarto (...) - „Alfredo otworzył i zamknął drzwi łazienki, zapalił papierosa, usiadł na muszli klozetowej, nie podnosząc klapy, spojrzał na zegarek, za piętnaście jedenasta (...)",

De alguna manera Ruth llegó al cuarto de baño (...) inclinó la cabeza sobre la taza del váter $y,(\ldots)$, vomitó - „W jakiś sposób Ruth dotarła do łazienki (...) pochyliła głowę nad muszlą klozetową i zwymiotowała".

$\underline{\text { Słowa pozostajace w tej samej formie gramatycznej, które uzyskały nowe znaczenie }}$ i funkcjonuja jako przymiotniki

aceituna ...) veo a unos cincuenta huérfanos en su uniforme verde aceituna - „(...) ridzę około pięćdziesięciu sierot w oliwkozielonych mundurach"; 
café La concha suele tener un tono café, marrón con rayas oscuras (...) „Muszla jest zazwyczaj w kolorze kawowym, brązowym z ciemnymi paskami (...)",

(...) con el cuerpo de una negra y los rasgos de una blanca sale la mujer perfecta, pero aqui mulatas no hay ni una, leche o café, no hay medias tintas, o una blanca con pinta de drogadicta (...) - „,...) z ciałem czarnej kobiety i rysami białej kobiety wychodzi kobieta idealna, ale tu nie ma ani jednej mulatki, mleko lub kawa, nie ma półśrodków, ani białej kobiety, która wygląda na narkomankę (...)";

słowo café uzyskało nowe znaczenie - jako kolor (które nie jest znaczeniem prymarnym ani $\mathrm{w} \mathrm{j}$. hiszpańskim, ani $\mathrm{w} \mathrm{j}$. arabskim), znaczenie hiszpańskie częściowo pokrywa się ze znaczeniem arabskim. Częściowo - ponieważ może też określać kolor skóry.

naranja $Y$ en esta foto (...) camisa naranja y corbata roja (...) - „A na tym zdjęciu (...) w pomarańczowej koszuli i czerwonym krawacie (...)",

(...) y pintado sobre un fondo de tela color naranja $(. .$.$) - „(...) i namalo-$ wane na tle $\mathrm{z}$ tkaniny koloru pomarańczowego (...)".

Słowa nabywające znaczenie przymiotnikowe w połączeniu z innymi częściami mowy

naranja (...) y entró al bar del enorme cartel naranja (...) - „(...) i wszedł do baru z ogromnym pomarańczowym szyldem (...)”;

aceituna El joven de piel de aceituna nos miró (...) - „Oliwkowoskóry młodzieniec spojrzał na nas (...)".

$\mathrm{W}$ j. arabskim stosowane do opisu ludzi (starzy jak az-zaytūna) w porównaniu do „drzewa”, co oznacza osobę szlachetną, o mocnych korzeniach, długowieczną, silną i hojną. W kolejnym znaczeniu określa np. koloru oczu - w znaczeniu „oliwka owoc”. W j. hiszpańskim występuje jako określenie koloru oczu oraz skóry. W odróżnieniu od poprzedniej grupy ta grupa łączy się z przyimkiem $d e$.

Słowa nadające znaczenie (innym rzeczom) przez porównanie

algodón Miré al hombre de pelo tan blanco y tenue como algodón y de ojos muy claros $(. .$.$) - „Spojrzałem na mężczyznę o włosach tak białych i cienkich$ jak bawełna i o bardzo jasnych oczach (...)".

Podobne porównania funkcjonują również w j. arabskim. $\mathrm{W}$ j. hiszpańskim zazwyczaj przyjmują formę z przyimkiem como (jak).

\section{Słowa, które tworza nazwy własne}

aceituna El Pato y la Aceituna. Son dos profes míos -explicó Miguel- „Pato i Oliwka to moi dwaj nauczyciele - wyjaśnił Miguel",

Estas aceitunas son de Aceitunas Andújar, una empresa de los Hermanos Moya - „Te oliwki są z Aceitunas Andújar, firmy Hermanos Moya”; 
café (...) hace muchos años que no existe el Café Suizo - „(...) Café Suizo nie istniej od wielu lat";

naranja (...) portavoz de la asociación Veteranos Americanos de Vietnam y presidente del Comité Nacional sobre el Agente Naranja - „,...) rzecznik prasowy Amerykańskich Weteranów Wojny w Wietnamie i przewodniczący Krajowego Komitetu ds. Pomarańczowego Agenta"34,

(...) la Revolución Naranja de Ucrania - „,...) Pomarańczowa Rewolucja na Ukrainie."

Słowa tworzące wyrażenia idiomatyczne

algodón Si quieres la pruebadel algodón, haz cosas que sabes que le molestan„Jeśli chcesz zrobić ostateczny test, rób rzeczy, o których wiesz, że mu przeszkadzają",

Hemos actuado entre algodones, Petra - „Działaliśmy delikatnie, Petra”;

almohada Lo he consultado con la almohada - dice - y no volveré a vestir (...) Przmyślałem to - mówi - i nie założę więcej (...)",

Olmo asegura en la grabación que lo tiene que ,consultar con la almoha$d a ”-$, Olmo zapewnia na nagraniu, że musi to przemyśleć (przespać się z tym)";

naranja Viriato es mi media naranja - „Viriato jest moją drugą połową”, (...) creo que he encontrado mi media naranja - „(...) sądzę, że znalazłem moją drugą połowę."

\section{Uwagi końcowe}

Jednym z uwarunkowań historycznych kultury i języka hiszpańskiego jest widoczny wpływ kultury i języka arabskiego, który rozpoczął się podbojem Półwyspu Iberyjskiego przez Berberów w VIII wieku (711 r.). Długotrwała obecność arabska na terenie obecnej Hiszpanii odcisnęła swe piętno na różnych dziedzinach życia. Wpływy te są obecne we współczesnej Hiszpanii w rozmaitych obszarach - m.in. w języku, architekturze, rolnictwie, medycynie, kuchni czy zachowaniach społecznych. Koegzystencja obu kultur doprowadziła do stworzenia nowych wartości kulturowych i tzw. cywilizacji hispanoarabskiej. Muzułmańska Hiszpania miała ogromne znaczenie dla obszarów lingwistycznych, w różnych sferach języka hiszpańskiego. Proces arabskiego oddziaływania na kulturę i język hiszpański przechodził różne etapy - od początków konstytuowania się j. hiszpańskiego, spuściznę Al-Andalus, po hiszpańszczyznę współczesną.

We współczesnym j. hiszpańskim można odnaleźć wiele wpływów arabskich na różnych płaszczyznach językowych, jednak najbardziej są one zauważalne na poziomie leksykalnym. Wskazaną obecność można wykazać za pomocą badań jakościowych oraz ilościowych. Pierwszy wskaźnik odwołuje się do sprawdzenia zinte-

\footnotetext{
${ }^{34}$ Ibidem.
} 
growania arabizmów w systemie gramatycznym i fonetycznym j. hiszpańskiego oraz bada zintegrowanie kulturowe poprzez pola semantyczne, uzus i pragmatykę społeczną. Drugi ze wskazanych parametrów odwołuje się do danych statystycznych (np. szacowanej obecności arabizmów w j. hiszpańskim uwzględniającej różne podejścia badawcze). Przy pogłębionych badaniach można mówić m.in. o wskaźniku dyspersji, częstości relacyjnej, ekstensji stylowej czy filiacji odmian różnostylowych j. hiszpańskiego ze względu na zapożyczenia z j. arabskiego.

Siła zintegrowania kulturowego przejawia się też tym, że przeciętni użytkownicy j. hiszpańskiego nie zdają sobie sprawy ze stosowania arabizmów w swoich codziennych wypowiedziach. Co oznacza, że arabskie zapożyczenia zakorzeniły się tak głęboko w kulturze i świadomości społecznej, że na co dzień pozostają niezauważone i nie są postrzegane jako elementy obce językowo (podobnie jak zapożyczenia $\mathrm{z}$ łac.). Poza dostrzeżeniem oczywistej wagi i znaczenia elementów kultury i j. arabskiego w kulturze i j. hiszpańskim właśnie ta cecha integracji zapożyczeń $\mathrm{z}$ j. arabskiego do j. hiszpańskiego wzbudza duże zainteresowanie badawcze naukowców reprezentujących różne dziedziny nauki.

W hiszpańskich badaniach językoznawczych i literaturoznawczych dotyczących arabskich zapożyczeń do hiszpańszczyzny pojawiają się różne aspekty i metody badawcze. Zasięg zjawiska na poziomie leksykalnym podkreśla fakt pojawienia się w j. hiszpańskim terminu arabismos (arabizmy) na jego określenie. Problematyka ta interesuje również badaczy zajmujących się innymi gałęziami nauki - co jest widoczne w rozpiętości zagadnień poruszanych w pracach i zakresie prowadzonych badań, powstające opracowania mają m.in. charakter historyczny, socjologiczny czy kulturowy. Należy zauważyć, że pierwsze opracowania leksykalne (słowniki wyrazów pochodzenia arabskiego) powstawały w XIX w. A kolejne liczne prace, takie jak np. słowniki tematyczne (dotyczące różnych obszarów: flora, fauna, medycyna) i wiele innych dotyczących różnych zagadnień i dziedzin potwierdziły wpływy arabskie na Półwyspie Iberyjskim i doprowadziły do konkluzji (Lapesa), że wpływ arabskiego na j. hiszpański kształtuje się na drugim miejscu po łacinie $\mathrm{Z}$ badań wynika, że wpływ kultury $\mathrm{i}$ j. arabskiego na kulturę $\mathrm{i}$ j. hiszpański jest procesem ciągłym i nadal aktualnym. Wykazują to również wyniki niniejszego opracowania. Jak można było zauważyć, słowa $\mathrm{z}$ materiału badawczego funkcjonują we współczesnym korpusie j. hiszpańskiego XXI wieku.

Przeprowadzone badania, pomimo charakteru przyczynkowego, potwierdziły zintegrowanie elementów arabskich z kulturą i j. hiszpańskim oraz nieustającą (od VIII w.) obecność tejże kultury w szeroko pojmowanej kulturze Hiszpanii. Dane przedstawione przez autorki pracy, w szczególności w rozdz. 2 i w rozdz. 5, potwierdzają ogólny nurt badań wskazujących na głębokie zakorzenienie elementów arabskich w kulturze i j. hiszpańskim. Autorki traktują prezentowane wyniki jako ogólne (próba reprezentatywna), które zachęcają do kontynuacji tej linii badawczej w przyszłości. Wyniki te stanowią też przykład możliwości badań prowadzonych 
z korpusem hiszpańszczyzny XXI w. i otwierają kolejne pola badawcze, które można poszerzyć, wzbogacając zarówno materiał, jak i zakres obszaru badań.

Podsumowując wyniki pracy i dane z poszczególnych jej rozdziałów, należy powtórzyć za innymi badaczami, że wpływ kultury i j. arabskiego na kulturę i j. hiszpański jest tak znaczący, że aby dogłębnie zrozumieć zjawiska językowe, kulturowe i społeczne Hiszpanii należy poznać i zrozumieć historię i kulturę arabską.

\section{Bibliografia}

Bajo Perez, E. 2000. Los diccionarios. Introducción a la lexicografia del español. Gijón: TREA.

Bańczerowski, J i J. Oueslati. 2020. „Quandaries over the Morphonology of the Verb in Modern Standard Arabic and Tunisian Arabic: a Tentative Draft". Scripta Neophilologica Posnaniensia XX. $23-41$.

Bańczerowski, J., Pogonowski, J. i T. Zgółka. 1982. Wstęp do językoznawstwa. Poznań: Wydawnictwo Naukowe UAM.

Bustamante Costa, J. 2016. „Alefanginas: el error gráfico como generador de variantes léxicas en los arabismos". Boletín de la Real Academia Española XCVI. Zeszyt CCCXIII.

Cano Aguilar, R. 1988. El español a través de los tiempos. Madryt: Arco Libros.

Cano, R. (red.). 2004. Historia de la lengua española. Barcelona: Ariel.

Carstensen, B. 1988. „Loan-translation: theoretical and practical issues”. Folia Linguistica 22. 85-92.

Chavarría Vargas, J. A. 1997. Contribución al estudio de la toponimia latino-mozárabe de la Axarquía de Málaga. Malaga.

Chomsky, N. 1995. The Minimalist Program. Cambridge, Mass.: MIT Press.

Chomsky, N. 2000. New Horizons in the Study of Language and Mind. Cambridge: Cambridge University Press.

Chomsky, N. 2005. O naturze i języku. Tłum. Lang, Jacek. Poznań: Axis.

Corriente Córdoba, F. 1981-1982. „Notas sobre la interferencia clásica en hispanoárabe”. Revista del Instituto Egipcio de Estudios Islámicos 21. 31-42.

Corriente Córdoba, F. 1992. Árabe andalusí y lenguas romances. Madrid.

Corriente Córdoba, F. 1996. "Hacia una revisión de los arabismos y otras voces con étimos del romance andalusí o lenguas medio-orientales en el Diccionario de la Real Academia Española”. Boletín de la Real Academia Española 76. Zeszyt 267. 55-118;

Corriente Córdoba, F. 1997a, La lexicografía árabe en España: pasado, presente y futuro, Pensamiento y circulación de las ideas en el Mediterráneo: el papel de la traducción. (red.) Miguel Hernando de Larramendi Martínez. 133-149.

Corriente Córdoba, F. 1997b. A dictionary of Andalusi Arabic. Leiden: Brill.

Corriente Córdoba, F. 1997c. Diccionario español-árabe. Barcelona: Herder.

Corriente Córdoba, F. 1998. „Arabismos dialectales del iberorromance central”. Estudios de dialectología norteafricana y andalusi EDNA 3. 65-124.

Corriente Córdoba, F. 1999. „Toponimia hispanoárabe en Aragón”. Qurtuba: Estudios andalusíes 4. $183-187$.

Corriente Córdoba, F. 2000. „Los arabismos en el español de Canarias”. Estudios Canarios: Anuario del Instituto de Estudios Canarios 45. 187-204.

Corriente Córdoba, F. 2003. Diccionario de arabismos y voces afines en iberorromance. Madryt: Gredos.

Corriente Córdoba, F. 2008. Dictionary of Arabic and allied loanwords: Spanish, Portuguese, Catalan, Galician and kindred dialects. Leiden: Brill. 
Doroszewski, W. 1938. Język polski w Stanach Zjednoczonych. Warszawa.

Galmés de Fuentes, Á. Sánchez Álvarez, Mercedes. Vespertino Rodríguez, Antonio. Villaverde Amieva, Juan Carlos. 1994. Glosario de voces aljamiado-moriscas. Oviedo.

Garulo Muñoz, T. 1983. Los arabismos en el léxico andaluz. Córdoba-Madrid.

Granja de la, F. 1998. „El problema del mudejarismo en la lengua y en la literatura”. Quruba, Estudios aldalusies 3. 183-194.

Haugen, E. 1950. "The analysis of linguistic borrowing". Language 26. 210-231 (https://www.jstor. org/stable/410058?read-now=1\&seq=1\#page_scan_tab_contents).

Lapesa, R. 1981. Historia de la lengua española (9 edycja). Madryt: Gredos.

Lapesa, R. 1985. Estudios de historia lingüistica española. Madryt: Paraninfo.

Lévy, S. 1995. „Palabras aventureras. Hispanismos olvidados, escondidos en hablas árabes de Marruecos". [W:] Mohammed Salhi (coord.). Huellas comunes y miradas cruzadas: Mundos árabe, ibérico e iberoamericano. Rabat. 187-196.

Llavero Ruiz, E. i A.R. Vidal Luengo. 2010. „Reflexiones sobre la interrelación léxica del árabe y el español a propósito de la enseñanza-aprendizaje del español como segunda lengua (L2)”. W zbiorze: Reyes, M.J. (red.) Léxico y cultura. Badajoz: Abecedario. 77-94.

Lyons, J. 1976. Wstęp do językoznawstwa. Tłum. Bogacki, Krzysztof. Warszawa: PWN.

Maćkiewicz, J. 1984. „Co to są tzw. internacjonalizmy”. Język Polski LXIV. 176-184.

Mańczak-Wohlfeld, E. 1995. Tendencje rozwojowe wspótczesnych zapożyczeń angielskich $w$ języku polskim. Kraków: Universitas (https://docer.pl/doc/5vnscn).

Oliver Asín, J. 1974. „En torno a los orígenes de Castilla. Su toponimia en relación con los árabes y los beréberes", Real Academia de la Historia, Discurso leído en el aco de su recepción pública, 24 marca 1974, MCMLXXIV. Madryt. 12-30.

Oueslati, J. 2015. The phonetic and phonological systems of the Dzira dialect of Tunisian Arabic. Poznań: Wydawnictwo Rys.

Oueslati, J. 2021. „French Loans in Tunisian Arabic from Phonetic and Phonological Perspective”. Rocznik Orientalistyczny T. LXXIV. 23-41.

Owens, J. (red.). 2000. Arabic as a minoritary language. Berlin.

REAL ACADEMIA ESPAÑOLA: Banco de datos (CORPES XXI) [online], Corpus del Español del Siglo XXI (CORPES) (http://www.rae.es).

REAL ACADEMIA ESPAÑOLA: Diccionario de la lengua española, 23 edycja, [wersja 23.4 online] (https://dle.rae.es).

Szałek, J. 2013. „Neologia we współczesnym języku hiszpańskim”. Scripta Neophilologica Posnaniensia XIII. 117-127.

Tuñón de Lara, M., Valdeón Baruque, J., Domínguez Ortiz, A. 1997. Historia Hiszpanii. Tłum. Szymon Jędrusiak. Kraków: Universitas.

Turek, W.P. 2001. Stownik zapożyczeń pochodzenia arabskiego w polszczyźnie. Kraków: Universitas.

Vidal-Luengo, A.R. 2007. „Vitalidad diacrónica y sincrónica de arabismos léxicos en el español atlántico: Madeira, Canarias, América". Studia Neophilologica 89.2. 1-21.

Viguera Molins, M. ${ }^{a}$ J. Lengua árabe y lenguas románicas. (http://revistas.ucm.es/index.php/RFRM/ article/viewFile/RFRM0202110045A/10746) (data dostępu: 05.2021).

Zaborski, A. 2002. „Wacław Przemysław Turek Stownik zapożyczeń pochodzenia arabskiego w polszczyźnie Universitas Kraków 2001, s. 560". Bulletin de la Société Polonaise de Linguistique LVIII. 201-213. 
